\title{
Miscellaneous notes
}

\section{POACEAE}

\section{CHROMOSOME STUDIES ON AFRICAN PLANTS. 17. THE SUBFAMILIES ARUNDINOIDEAE AND DANTHONIOIDEAE}

Cytogenetic studies in our laboratory focused on the former grass subfamily Arundinoideae and we have published chromosome numbers of 422 specimens, representing 12 genera and 54 species (Du Plessis \& Spies 1988; Spies \& Du Plessis 1988; Spies et al. 1990, 1992; Du Plessis \& Spies 1992; Spies et al. 1994; Visser \& Spies 1994b, d, e; Klopper et al. 1998; Spies \& Roodt 2001). This subfamily was recently subdivided into two separate subfamilies, the Arundinoideae and Danthonioideae by the Grass Phylogeny Working Group (GPWG 2001): the Arundinoideae, represented by Styppeiochloa De Winter, has basic chromosome numbers of 6, 9 and 12 and the Danthonioideae, represented by Chaetobromus Nees, Karroochloa Conert \& Türpe, Merxmuellera Conert, Pentameris P.Beauv., Pentaschistis Stapf, Pseudopentameris Conert, Schismus P.Beauv. and Tribolium Desv., has $\mathrm{x}=6,7$ and 9 .

This is a chromosome number report for the two subfamilies.

\section{MATERIALS AND METHODS}

Cytogenetic material of identical plants of a population was collected and fixed in the field. Voucher specimens, listed in Table 1, are housed in the Geo Potts
Herbarium, Department of Botany and Genetics, University of the Free State, Bloemfontein (BLFU) or in the National Herbarium, Pretoria (PRE).

Anthers were squashed in aceto-carmine and meiotically analysed - at least 20 cells per meiotic stage were studied (Spies et al. 1996). Only gametic chromosome numbers are presented to conform to previous papers on chromosome numbers in this journal (Spies \& Du Plessis 1986).

\section{RESULTS AND DISCUSSION}

One hundred and nineteen plants, representing 38 species and 9 genera, were studied (Table 1).

\section{Arundinoideae}

Three specimens of the monospecific genus Styppeiochloa, S. gynoglossa, were studied. Two specimens had $n=2 x=12$, and one octaploid specimen $(n=4 x=$ 24) was found (Figure 1A). These specimens represent the first known chromosome number reports for this genus and six is the original basic chromosome number. Twelve is probably a secondarily derived basic chromosome number.

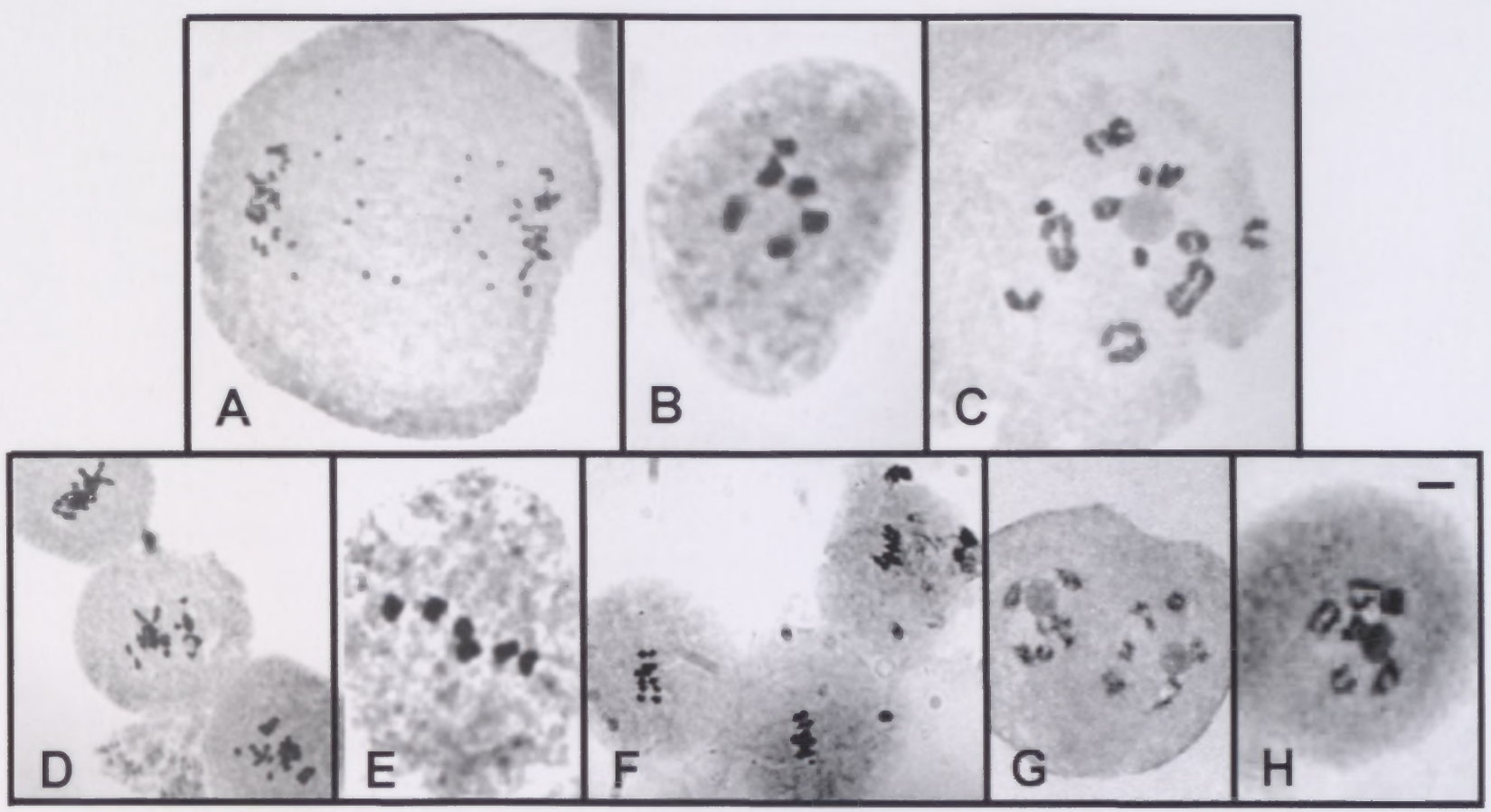

FIGURE 1.-Meiotic chromosomes in Styppeiochloa and Karroochloa. A, Styppeiochloa gynoglossa, Saayman 79, $2 \mathrm{n}=8 \mathrm{x}=48$, with chromosomal laggards; B, Karroochloa curva, Spies 45/8, $2 n=2 \mathrm{x}=12$, diakinesis with $6_{n}$ C - E, K. purpurea: C, D, Spies $2473,2 n=4 x=24+2-5 B$; C, diakinesis with $3{ }_{\mathbb{1 v}} 6_{\|}$and $5 \mathrm{~B}$ (two B chromosomes paired); D, metaphase I with B chromosomes not on metaphase plate; E, Spies 2477 , $2 \mathrm{n}=2 \mathrm{x}=12$, metaphase I. F, G, K. schismoides: F, Spies $3371,2 \mathrm{n}=2 \mathrm{x}=12$, metaphase I; G, Spies $3382,2 \mathrm{n}=2 \mathrm{x}=12$, cell fusion resulting in 12 bivalents and two micronuclei during diakinesis. H, Karroochloa species, Spies $5192,2 \mathrm{n}=2 \mathrm{x}=12$, diakinesis with 6 . Scale bar: B, $5 \mu$ m; B, C, E, H, $8 \mu \mathrm{m} ; \mathrm{D}, \mathrm{F}, \mathrm{G}, 15 \mu \mathrm{m}$. 
TABLE 1 - Gametic chromosome numbers $(n)$ of representatives of subfamilies Arundinoideae and Danthonioideae (Poaceae) in southern Africa with their voucher specimen numbers and specific localities. Species are listed alphabetically and localities presented according to Edwards \& Leistner (1971)

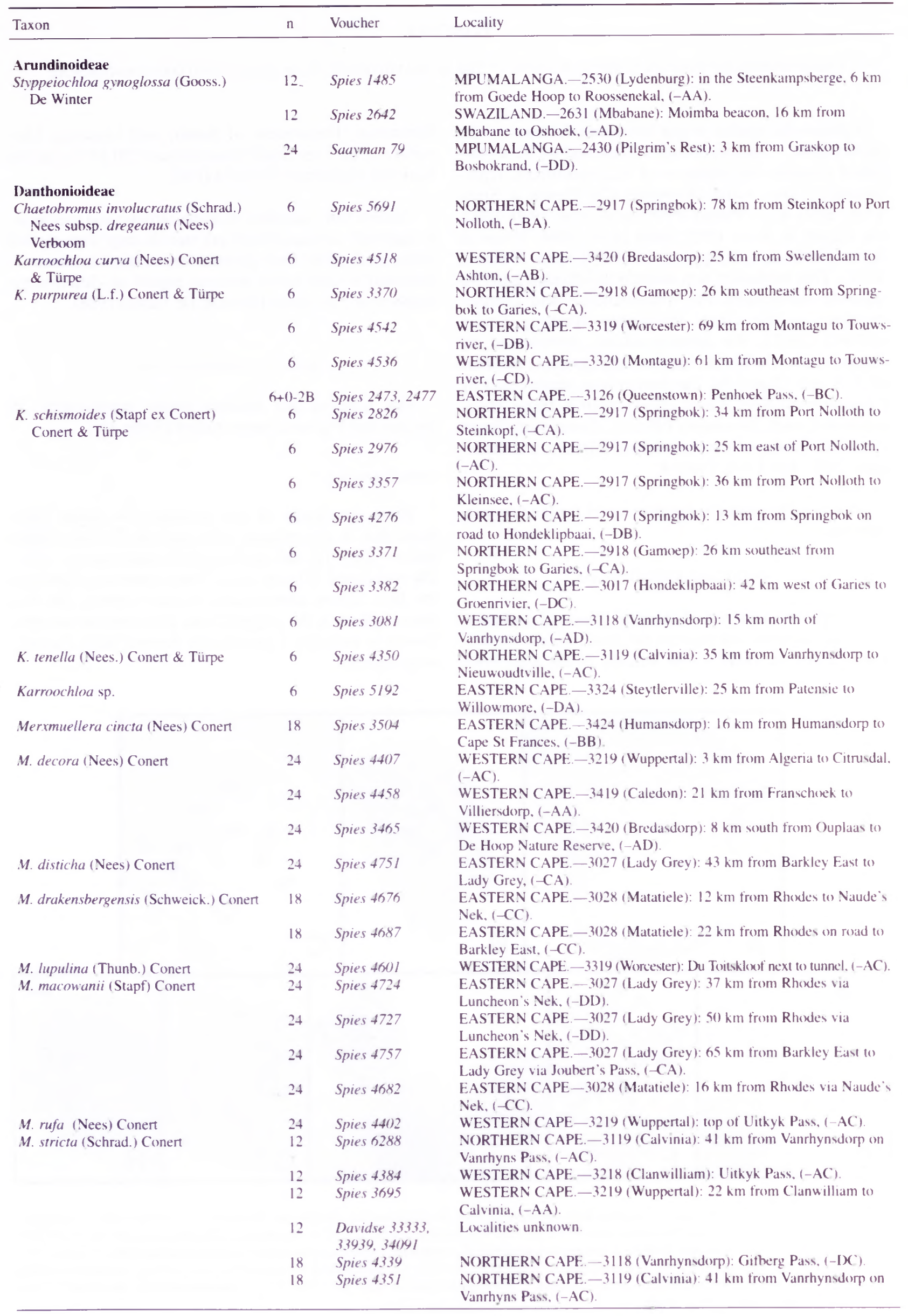


TABLE 1.-Gametic chromosome numbers ( $\mathrm{n}$ ) of representatives of subfamilies Arundinoideae and Danthonioideae (Poaceae) in southern Africa with their voucher specimen numbers and specific localities. Species are listed alphabetically and localities presented according to Edwards \& Leistner (1971) (cont.)

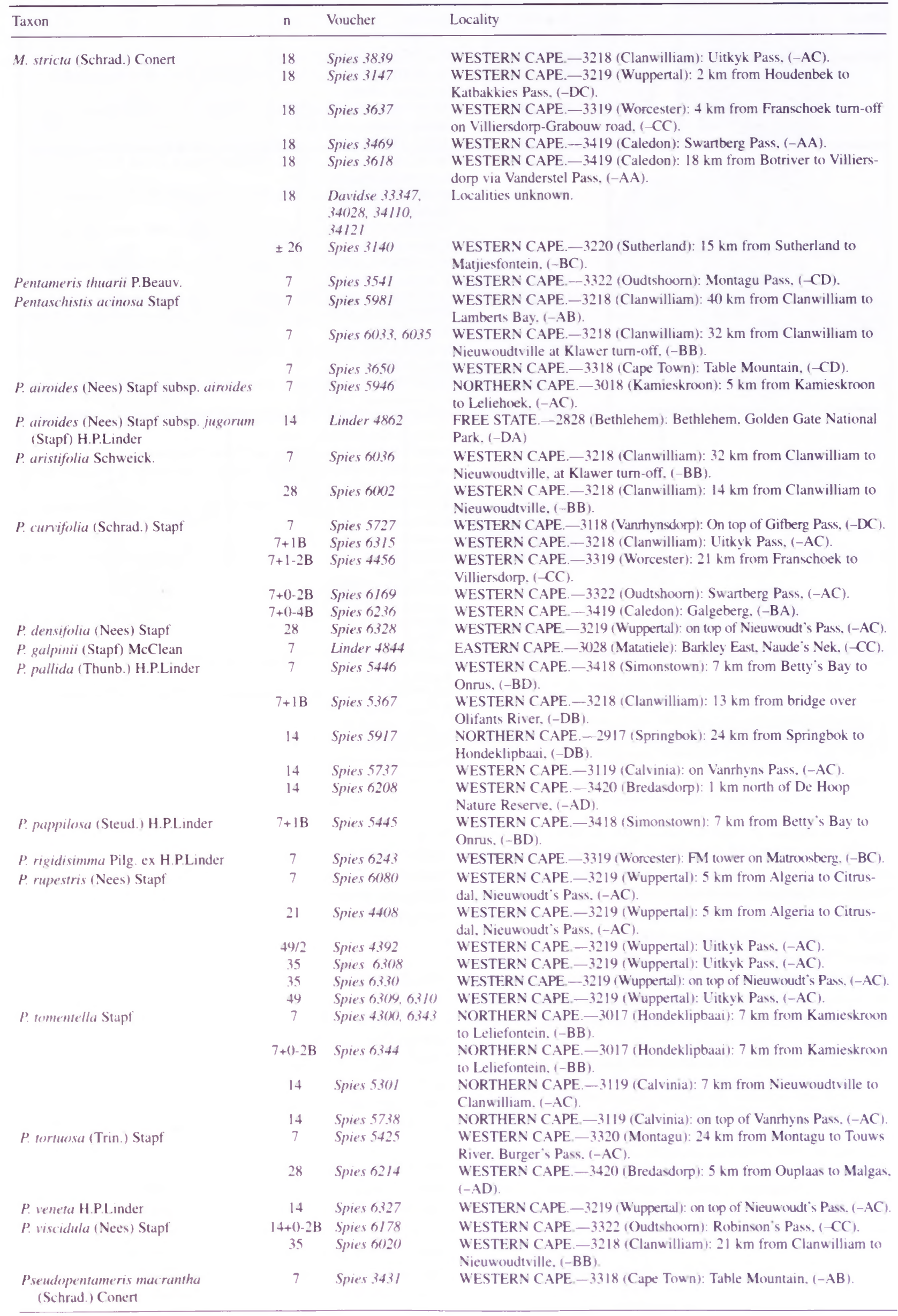


TABLE 1. - Gametic chromosome numbers ( $\mathbf{n}$ ) of representatives of subfamilies Arundinoideae and Danthonioideae (Poaceae) in southern Africa with their voucher specimen numbers and specific localities. Species are listed alphabetically and localities presented according to Edwards \& Leistner (1971) (cont.)

\begin{tabular}{|c|c|c|c|}
\hline Taxon & $\mathrm{n}$ & Voucher & Locality \\
\hline \multirow[t]{11}{*}{ Schismus barbatus (Loefl. ex L.) Thell. } & 6 & Spies 5284 & GAUTENG.-2528 (Pretoria): Pretoria, (-CA). \\
\hline & 6 & Spies 4273 & $\begin{array}{l}\text { NORTHERN CAPE-_-2917 (Springbok): } 2 \text { km from Springbok to } \\
\text { Pofadder, (-DB). }\end{array}$ \\
\hline & 6 & $\begin{array}{l}\text { Spies } 4277 \\
4278,4285\end{array}$ & $\begin{array}{l}\text { NORTHERN CAPE.-2917 (Springbok): } 13 \mathrm{~km} \text { from Springbok to } \\
\text { Hondeklipbaai, (-DB). }\end{array}$ \\
\hline & 6 & Spies 6596 & FREE STATE-2925 (Jagersfontein): Petrusburg, (-AB). \\
\hline & 6 & Spies 4289 & $\begin{array}{l}\text { NORTHERN CAPE.-3017 (Hondeklipbaai): } 24 \mathrm{~km} \text { from Soebatsfon- } \\
\text { tein to Kamieskroon, (-BA). }\end{array}$ \\
\hline & 6 & Spies 4315 & $\begin{array}{l}\text { NORTHERN CAPE.-3018 (Kamiesberg); } 28 \mathrm{~km} \text { from Leliefontein to } \\
\text { Garies, (-AB). }\end{array}$ \\
\hline & 6 & Spies 4366 & $\begin{array}{l}\text { WESTERN CAPE-3119 (Calvinia): } 55 \mathrm{~km} \text { from Nieuwoudtville to } \\
\text { Clanwilliam, (-CC). }\end{array}$ \\
\hline & 6 & $\begin{array}{l}\text { Davidse } 34033 \text {, } \\
34039\end{array}$ & $\begin{array}{l}\text { WESTERN CAPE. }-3219 \text { (Wuppertal): } 44 \mathrm{~km} \text { from Clanwilliam to } \\
\text { Calvinia, (-AA). }\end{array}$ \\
\hline & 6 & Spies 5342 & WESTERN CAPE._-3318 (Vanrhynsdorp): Vanrhynsdorp, (-DA). \\
\hline & 6 & Spies 4523 & $\begin{array}{l}\text { WESTERN CAPE.-3320 (Montagu): } 24 \mathrm{~km} \text { from Montagu to Touws } \\
\text { River, }(-\mathrm{CC} \text { ). }\end{array}$ \\
\hline & 6 & Spies 4524 & $\begin{array}{l}\text { WESTERN CAPE-3320 (Montagu): } 38 \mathrm{~km} \text { from Montagu to Touws } \\
\text { River. (-CC). }\end{array}$ \\
\hline \multirow[t]{6}{*}{ S. inermis (Stapf) C.E. Hubb } & 6 & Spies 4308 & $\begin{array}{l}\text { NORTHERN CAPE.-3017 (Hondeklipbaai): } 18 \mathrm{~km} \text { from Kamieskroon } \\
\text { to Leliefontein, (-BA). }\end{array}$ \\
\hline & 6 & Spies 4311 & $\begin{array}{l}\text { NORTHERN CAPE.-3018 (Kamiesberg): } 3 \mathrm{~km} \text { from Leliefontein to } \\
\text { Garies in Groenkloof, }(-\mathrm{AB} \text { ). }\end{array}$ \\
\hline & 6 & Spies 4575 & WESTERN CAPE.-3318 (Cape Town): Langebaan, (-DC). \\
\hline & 6 & Davidse 33758 & $\begin{array}{l}\text { WESTERN CAPE. }-3421 \text { (Riversdale): } 2 \mathrm{~km} \text { south of Vermaaklikheid } \\
\text { on road to Puntjie. }(-\mathrm{AC}) \text {. }\end{array}$ \\
\hline & 12 & Spies 4471 & $\begin{array}{l}\text { WESTERN CAPE. - } 3420 \text { (Bredasdorp): } 1 \mathrm{~km} \text { from Waenhuiskrans to } \\
\text { Bredasdorp. (-CA). }\end{array}$ \\
\hline & 12 & Davidse 33804 & Locality unknown. \\
\hline \multirow[t]{2}{*}{ S. scaberrimus Nees } & 6 & Spies 4661 & $\begin{array}{l}\text { NORTHERN CAPE.-3121 (Fraserburg): } 55 \mathrm{~km} \text { from Loxton to Fraser- } \\
\text { burg, (-DB). }\end{array}$ \\
\hline & 6 & Spies 4660 & $\begin{array}{l}\text { NORTHERN CAPE. - } 3220 \text { (Sutherland): } 2 \mathrm{~km} \text { from Sutherland to } \\
\text { Calvinia. (-BC). }\end{array}$ \\
\hline Tribolium acutiflorum (Nees) Renvoize & 12 & Spies 3866 & $\begin{array}{l}\text { WESTERN CAPE- } 3319 \text { (Worcester): } 5 \mathrm{~km} \text { from Gouda to Porterville, } \\
(-\mathrm{AC} \text { ). }\end{array}$ \\
\hline \multirow[t]{2}{*}{ T. hispidum (Thunb.) Desv. } & 6 & Spies 4496 & $\begin{array}{l}\text { WESTERN CAPE. - } 3420 \text { (Bredasdorp): } 1 \mathrm{~km} \text { north of De Hoop Nature } \\
\text { Reserve. (-CA). }\end{array}$ \\
\hline & 12 & Spies 3509 & $\begin{array}{l}\text { EASTERN CAPE. - } 3424 \text { (Humansdorp): } 30 \mathrm{~km} \text { from Humansdorp to } \\
\text { Knysna, (-AA). }\end{array}$ \\
\hline T. obtusifolium (Nees) Renvoize & 18 & Davidse 34049 & Locality unknown. \\
\hline T. pusillum (Nees) H.P.Linder \& Davidse & 6 & Davidse 34022 & $\begin{array}{l}\text { WESTERN CAPE.-3218 (Clanwilliam): } 7 \mathrm{~km} \text { from Clanwilliam in } \\
\text { Pakhuis Pass, (-BB). }\end{array}$ \\
\hline T. uniolae (L.f.) Renvoize & $12+0-2 B$ & Davidse 34166 & Locality unknown. \\
\hline
\end{tabular}

The two tetraploid specimens, Spies 1485,2642 , with $x$-values of 0.829 and 1 respectively, agree with the $2: 2$ model of Kimber \& Alonso (1981) (Table 2). The high $\mathrm{x}$-value of Spies 1485 indicates segmental alloploidy, with a tendency towards alloploidy. The other specimen, Spies 2642, has a value of 1 , suggesting an alloploid origin. In both specimens mostly bivalents were observed. In Spies 1485, multivalent formation was rarely observed, but in Spies 2642 only rod and ring bivalents

TABLE 2. Genomic relationships in tetraploid Styppeiochloa specimens analysed according to Kimber \& Alonso (1981). Values indicated represent the sums of squares calculated for the four possible tetraploid models. $x$-values are indicated in parentheses. Model best suited for each specimen is indicated in bold

\begin{tabular}{cccccc}
\hline $\begin{array}{c}\text { Voucher } \\
\text { no. }\end{array}$ & $\begin{array}{c}\text { Chiasma } \\
\text { frequency }\end{array}$ & $\begin{array}{c}4: 01 \\
\text { mode }\end{array}$ & $\begin{array}{c}3: 1 \\
\text { model }\end{array}$ & $\begin{array}{c}\mathbf{2 : 2} \\
\text { model }\end{array}$ & $\begin{array}{c}2: 1: 1 \\
\text { model }\end{array}$ \\
\hline Spies 1485 & 0.86 & 3.688 & $\begin{array}{c}3.973 \\
(0.9485)\end{array}$ & $\begin{array}{c}\mathbf{0 . 4 1 6} \\
\mathbf{( 0 . 8 2 9 )}\end{array}$ & $\begin{array}{c}0.458 \\
(0.9389)\end{array}$ \\
Spies 2642 & 0.81 & 6.570 & $\begin{array}{c}7.135 \\
(0.92)\end{array}$ & $\begin{array}{c}\mathbf{0 . 0 0 0 9 0 3} \\
(\mathbf{1})\end{array}$ & $\begin{array}{c}1.835 \\
(1)\end{array}$ \\
\hline
\end{tabular}

were observed, evidence of alloploidy. The formation of mainly bivalents indicates an alloploid or segmental alloploid origin, thus suggesting a hybrid origin for this monotypic genus.

\section{Danthonoideae}

A single specimen of Chaetobromus involucratus subsp. dregeanus was investigated with $\mathrm{n}=\mathrm{x}=6$. This confirms a basic chromosome number of six for this genus, endemic to the semi-arid and arid western Cape region of South Africa and the extreme southwestern corner of Namibia (Du Plessis \& Spies 1988; Spies \& Du Plessis 1988; Spies et al. 1990; Verboom \& Linder 1997). Studies of the genus Chaetobromus by Spies et al. (1990) suggested a polyploid complex, ranging from diploid to duodecaploid. Polyploidy occurs as segmental alloploidy or occasionally as alloploidy (Spies et al. 1990). Spies et al. (1990) reported on extensive morphological, cytogenetical and anatomical variation in Chaetobromus, indicating hybridization and polyploidy. 


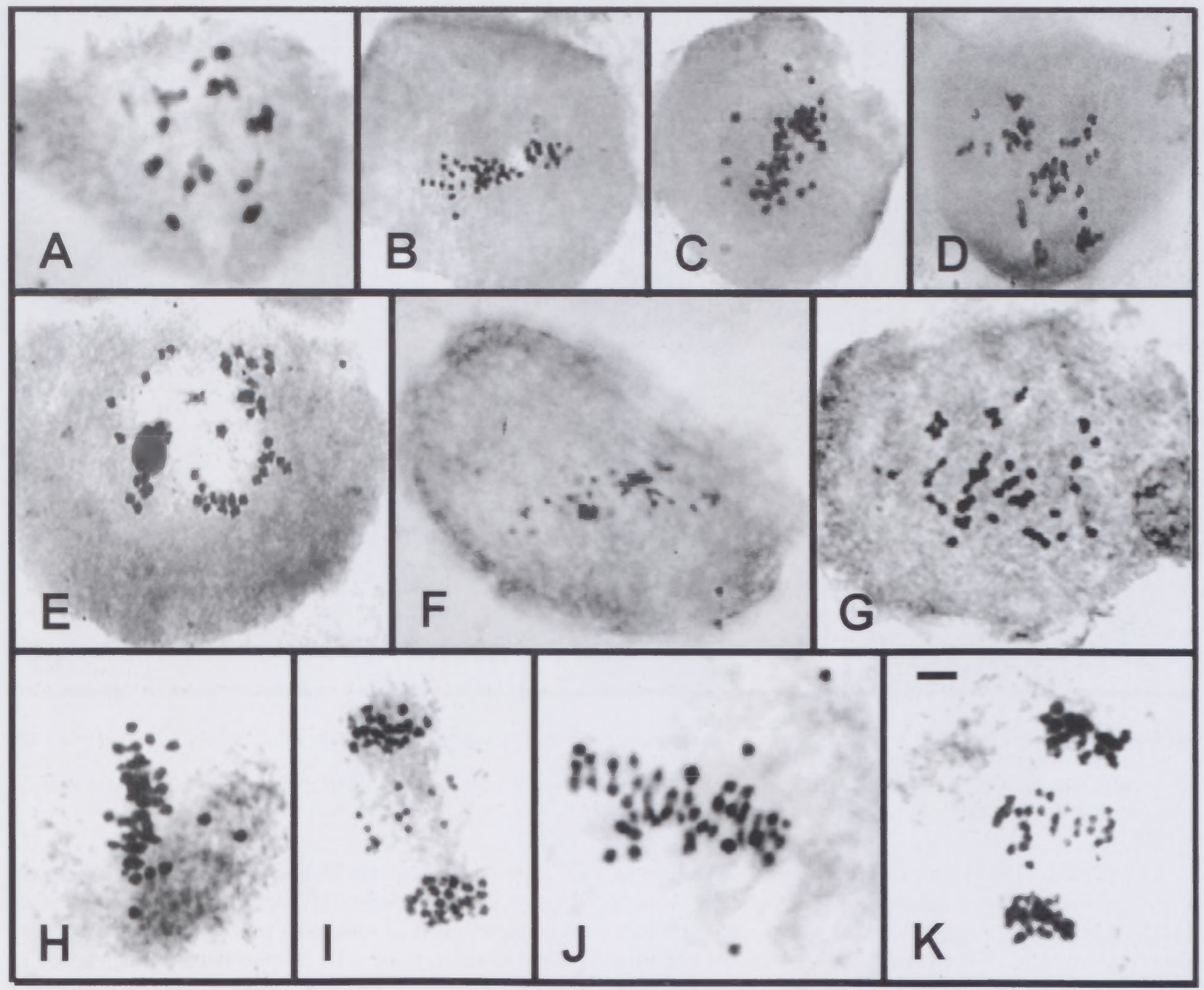

FIGURE 2.-Meiotic chromosomes in Merxmuellera. A, M. cincta, Spies 3504, $2 \mathrm{n}=6 \mathrm{x}=36$, diakinesis with $18_{\mathrm{n}}$, three bivalents are not in focus on this photograph. B, C, M. decora: B, Spies 4407, $2 \mathrm{n}=8 \mathrm{x}=48$, metaphase I; C, Spies 4458, $2 \mathrm{n}=8 \mathrm{x}=48$, metaphase I. D, $M$. drakensbergensis, Spies $4687,2 \mathrm{n}=6 \mathrm{x}=36$, early anaphase I 18-18 segregation; E, M. lupulina, Spies $4601,2 \mathrm{n}=8 \mathrm{x}=48$, diakinesis with 24 ; F, M. macowanii, Spies 4727, $2 \mathrm{n}=8 \mathrm{x}=48$, metaphase I; G, M. rufa, Spies 4402, $2 \mathrm{n}=8 \mathrm{x}=48$, diakineses. H-K, $M$. stricta, Spies 3140, $2 \mathrm{n}=9 \mathrm{x}=54: \mathrm{H}, \mathrm{J}$, metaphase I with various univalents; I, K, anaphase I with numerous laggards. Scale bar: A, E, F, G, J, $5 \mu$ m; B, C, D, $\mathrm{H}, \mathrm{I}, \mathrm{K}, 9 \mu \mathrm{m}$.

Diploid chromosome numbers $(n=x=6)$ were observed for all of the Karroochloa specimens studied, (Figure 1B-H) namely Karroochloa curva, K. schismoides and $K$. tenella. One $K$. curva specimen was studied cytogenetically and a low percentage of univalents (Spies 4518, Figure 1B) was observed. Two to five B chromosomes were observed in a single $K$. purpurea specimen (Spies 2473, Figure 1C, D) and this was also the only tetraploid specimen found. Further $K$. purpurea specimens exhibited normal meiosis (Figure IE, F). In $K$. chismoides meiosis was normal (Figure $1 \mathrm{~F}, \mathrm{H}$ ), but cell fusion was observed in some specimens (Spies 3382, Figure 1G) which could lead to polyploidy. The basic chromosome number of six was confirmed for this genus (Du Plessis \& Spies 1988; Spies \& Du Plessis 1988).

Chromosome numbers are reported for eight of the 18 southern African species of the genus Merxmuellera. The genus has a basic chromosome number of six (Du Plessis \& Spies 1988; Spies \& Du Plessis 1988). A single $M$. cincta specimen was investigated and found to be hexaploid (Figure 2A). All three $M$. decora specimens were octaploid $(\mathrm{n}=4 \mathrm{x}=24)$ (Figure 2B, C). Meiosis was abnormal with a high percentage of laggards during anaphase I (Figure 2C) and micro-nuclei during telophase I. In $M$. disticha meiosis was very abnormal with a high percentage of univalents during metaphase I, anaphase I laggards and micro-nuclei. This is the first report for $M$. drakensbergensis, both specimens being hexaploid $(\mathrm{n}=3 \mathrm{x}=18)$ (Figure 2D). Only one M. lupuli$n a$ specimen was investigated for the first time with $\mathrm{n}=$ $4 \mathrm{x}=24$ (Figure 2E). All four M. macowanii specimens were octaploid (Figure 2F). An octaploid chromosome count for M. rufa is a first for this species (Figure 2G). Several multivalents are evident in various cells of this specimen. A large number of the specimens were $M$. stricta. Mostly tetraploid and hexaploid numbers, or deviations thereof, (Spies $3140,2 \mathrm{n}=6 \mathrm{x}=51$ ) (Figure $2 \mathrm{H}-\mathrm{K}$ ) were evident. Meiotic irregularities such as univalents (Figure 2H, J), laggards (Figure 2I, K) and micro-nuclei as well as cytomixis were observed. This abnormal meiotic behaviour in the genus and especially M. stricta would suggest these specimens to be of hybrid origin. Many M. stricta specimens were found to contain a high number of chromosomal laggards, and it is a variable perennial species. 


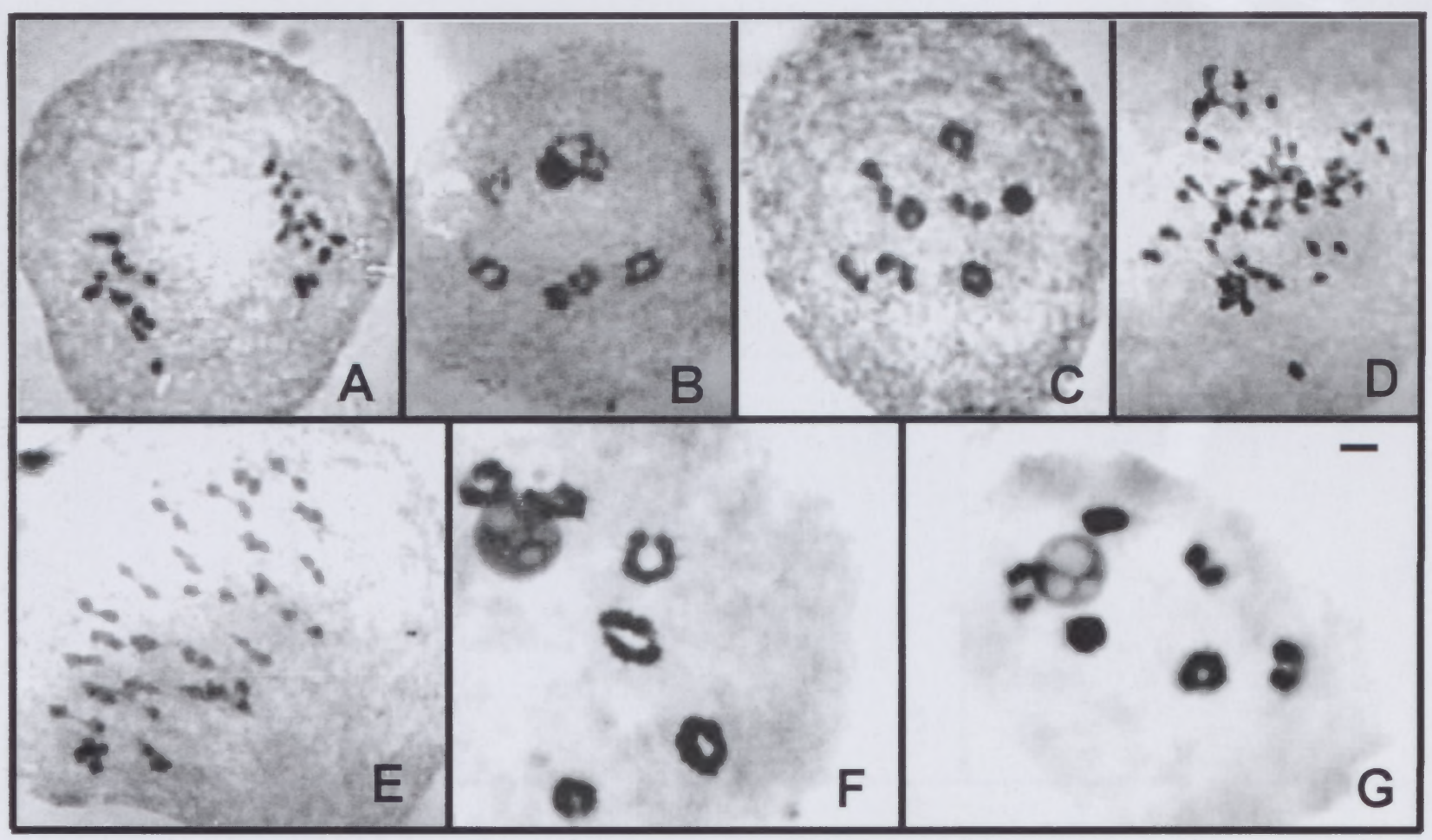

FIGURE 3.-Meiotic chromosomes in Pentaschistis and Pseudopentameris. A, Pentaschistis pallida, Spies $6208,2 \mathrm{n}=4 \mathrm{x}=28$, anaphase I with 14-14 segregation; B, P. rigidissima, Spies $6243,2 \mathrm{n}=2 \mathrm{x}=14$, diakinesis with $7_{\mathrm{ll}} ; \mathrm{C}$, P. tomentella, Spies $6344,2 \mathrm{n}=2 \mathrm{x}=14+0-2 \mathrm{~B}$, diakinesis with $7_{11} ; \mathrm{D}, \mathrm{E}, P$ tortuosa, Spies $6214,2 \mathrm{n}=8 \mathrm{x}=56$, early anaphase I with chromosomes starting to segregate. F, G, Pseudopentameris macrantha, Spies $3431,2 \mathrm{n}=2 \mathrm{x}=12$, diakinesis with $6_{\mathrm{II}}$ in each cell. Scale bar: B, F, G, $6 \mu \mathrm{m} ; \mathrm{A}, \mathrm{C}-\mathrm{E}, 10 \mu \mathrm{m}$.

Chippindall (1955) states that 'There is considerable variation in the plants referred to as Danthonia stricta (M. stricta), and it is possible that they comprise more than one variety'. Ellis (1980) divided M. stricta into four 'forms': the 'typical form' (M. stricta), the 'Drakensberg form' (M. stricta), the 'Cathedral Peak form' (M. guillarmodiae Conert) and the 'alpine form' (M. guillarmodiae). Each of these forms exhibits distinct epidermal structure and leaf anatomy. In the Drakensberg region, two Pentaschistis species displayed remarkable anatomical similarities with $M$. stricta. These are Pentaschistis tysonii Stapf and an unnamed Pentaschistis species. Anatomically they seem to show greater affinity with the M. stricta group than with Pentaschistis (Ellis 1980). This raises the issue as to whether hybridization occurred, or is still occurring between the different $M$. stricta forms, or between the Pentaschistis species and M. stricta, and whether this could clarify the possible hybrid nature of $M$. stricta.

One diploid Pentameris thuarii specimen was studied $(\mathrm{n}=\mathrm{x}=7)$. This confirms a basic chromosome number of seven for the genus (Spies \& Roodt 2001).

In the genus Pentaschistis, 14 of the 57 indigenous south African species (Gibbs Russell et al. 1990) were studied. This is the first report for numbers in $P$. acinosa $(\mathrm{n}=\mathrm{x}=7)$, $P$. galpinii $(\mathrm{n}=\mathrm{x}=7)$ and $P$. veneta $(\mathrm{n}=2 \mathrm{x}=14)$. Diploidy was observed in 21 of the 39 specimens (Figure 3B, C). Polyploidy is frequently encountered in Pentaschistis. In the study by Du Plessis \& Spies (1992), 59\% of the species investigated were polyploid, or had different polyploid levels. In this study tetraploidy was observed in $P$. airoides, $P$. pallida (Spies 5737, 5917, 6208) (Figure 3A), P. tomentella (Spies 5301, 5738), P. veneta and $P$. viscudula. Hexaploid
(P. rupestris), octaploid (P. densifolia, P. lima, P. tortuosa) (Figure 3D, E), decaploid (P. rupestris, $P$. viscidula) and up to 14-ploid levels ( $P$ rupestris) were also observed. Higher ploidy levels in some cells of specimens can be caused by cell fusion (Spies \& Van Wyk 1995). It is not an uncommon phenomenon in this genus.

Polyploidy is frequent in Pentaschistis. Klopper et al. (1998) reported on the existence of young polyploid complexes in 17 species. Twelve species were found to be old polyploid complexes, but were not adequately studied and the age of the complexes should be verified. Furthermore, Klopper et al. (1998) suggest that the genus Pentaschistis is a young polyploid hybrid complex.

B chromosomes were mostly encountered at the diploid level $(33 \%$ of the diploid specimens having 1 to 4 B chromosomes present in some cells). In P.entaschistis, the number of B chromosomes per cell varied within the same species and even within the same specimen. This is evident in P. curvifolia (Spies 4456, 6169, 6236,6315 ) where the number of $\mathrm{B}$ chromosomes varied from $0-4$ in the different specimens. B chromosomes were also encountered in the tetraploid $P$. viscidula specimen $(0-2 \mathrm{~B})$ but were absent from higher polyploid levels.

Only four genera, namely Merxmuellera, Pentameris, Pentaschistis and Prionanthium Desv., share the basic chromosome number of seven. Davidse et al. (1986) suggested that $x=7$ is a primitive number, as in the genus Pentaschistis, and that $\mathrm{x}=13$, which also occurs in the genus, was secondarily derived through an aneuploid reduction from $x=14$. In this study no specimens with a basic chromosome number of 13 were observed. 


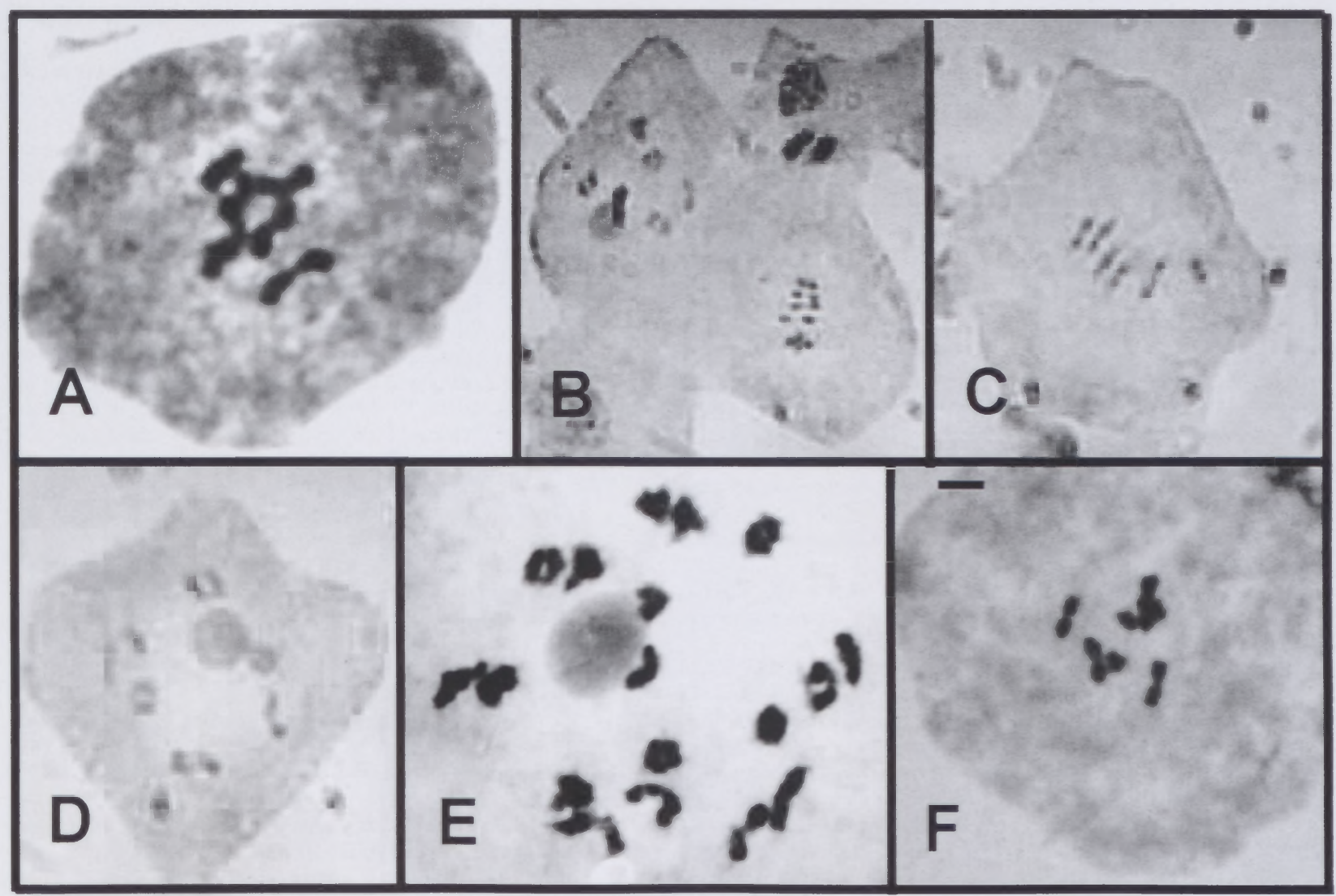

FIGURE 4.-Meiotic chromosomes in Schismus and Tribolium. A, S. barbatus, Davidse 34033, 2n = 2x = 12, early metaphase I. B-D, S. scaberrimus: B, C, Spies 4660, $2 \mathrm{n}=2 \mathrm{x}=12$, metaphase I; D, Spies 4661, $2 \mathrm{n}=2 \mathrm{x}=12$, diakinesis with 6 II. E, T. obtusifolium, Davidse 34049, $2 \mathrm{n}=6 \mathrm{x}=36$, diakinesis with $18_{\mathrm{II}} ; \mathrm{F}, T$. pusillum, Davidse $34022,2 \mathrm{n}=2 \mathrm{x}=12$, diakinesis with 6 . Scale bar: A, F, $5 \mu \mathrm{m}$; B-E, $10 \mu \mathrm{m}$.

One single specimen in the genus Pseudopentameris is reported here for the first time, $P$. macrantha with 2 n $=2 \mathrm{x}=12$ (Figure $3 \mathrm{~F}, \mathrm{G})$, and a basic chromosome number of six for the genus.

Three of the four endemic Schismus species were investigated cytogenetically. With the exception of a single $S$. inermis specimen (Davidse 33804), all the specimens were diploid, $2 n=2 x=12$, (Figure $4 A-D$ ) and confirms the basic chromosome number of six for the genus (Du Plessis \& Spies 1988; Spies \& Du Plessis 1988).

Du Plessis \& Spies (1988) reported a polyploid complex in Schismus barbatus, based on the meiotic behaviour of one diploid, three tetraploid and one hexaploid specimen. However, all $14 \mathrm{~S}$. barbatus specimens of this study were diploid.

The genus Tribolium was thoroughly investigated cytogenetically over the last couple of years (Spies et al. 1992; Visser \& Spies 1994a-e). It was concluded that six is the basic chromosome number for the genus. Six additional specimens representing five species were investigated. Diploidy $2 \mathrm{n}=2 \mathrm{x}=12$ was encountered in the species T. hispidum and T. pusillum (Figure 4F). Tribolium acutiflorum, $T$. hispidum and $T$ uniolae were found to be tetraploid and a single hexaploid specimen, T. obtusifolium was found (Figure 4E). We and Visser \& Spies (1994b) found diploid and tetraploid specimens in T. hispidum. In Tribolium polyploidy is common. This led Visser \& Spies (1994b, d, e) to conclude that the genus Tribolium is a polyploid complex. Visser \& Spies (1994d) reported on a T. uniolae hybrid swarm in which polyploidy is frequent and various meiotic abnormalities occur. 0-2 B chromosomes were observed, but only in the single $T$. uniolae specimen.

The basic chromosome numbers of six and seven for the Danthonioideae and six for Styppeiochloa (Arundinoideae) is confirmed.

\section{ACKNOWLEDGEMENTS}

The University of the Free State and the Foundation for Research and Development are thanked for financial assistance. Gerrit Davidse (Missouri Botanical Garden, USA) and Peter Linder (Institut für Systematische Botanik, Zürich) are thanked for providing some of the meiotic material used.

\section{REFERENCES}

CHIPPINDALL, L.K.A. 1955. A guide to the identification of grasses in South Africa. In C. Meredith, The grasses and pastures of South Africa: 1-527. Central News Agency, Cape Town.

DAVIDSE, G., HOSHINO, T. \& SIMON, B.K. 1986. Chromosome counts of Zimbabwean grasses and an analysis of polyploidy in the grass flora of Zimbabwe. South African Journal of Botany 52: $521-528$

DU PLESSIS, H. \& SPIES, J.J. 1988. Chromosome studies on African plants. 8. Bothalia 18: 119-122.

DU PLESSIS, H. \& SPIES, J.J. 1992. Chromosome numbers in the genus Pentaschistis (Poaceae, Danthonieae). Taxon 41: 709-720.

EDWARDS, D. \& LEISTNER, O.A. 1971. A degree reference system for citing biological records in southem Africa. Mitteilungen der Botanischen Staatssammlung, München 10: 501-509. 
ELLIS, R.P. 1980. Leaf anatomy of the South African Danthonieae (Poaceae). III. Merxmuellera stricta. Bothalia 13: 191-198.

GIBBS RUSSELL, G.E., WATSON, M., KOEKEMOER, M., SMOOK, L. BARKER, N.P., ANDERSON, H.M. \& DALLWITZ, M.J. 1990. Grasses of southern Africa. Memoirs of the Botanical Survey of South Africa No. 58.

GRASS PHYLOGENY WORKING GROUP (GPWG). 2001. Phylogeny and subfamilial classification of the grasses (Poaceae). Annals of the Missouri Botanical Garden 88: 373-457.

KIMBER, G. \& ALONSO, L.C. 1981. The analysis of meiosis in hybrids III. Tetraploid hybrids. Canadian Journal of Genetics and Cytology 23: 235-254

KLOPPER, K.C., SPIES, J.J. \& VISSER, B. 1998. Cytogenetic studies in the genus Pentaschistis (Poaceae: Arundinoideae). Bothalia 28: $231-238$.

SPIES, J.J., DAVIDSE, G. \& DU PLESSIS, H. 1992. Cytogenetic studies in the genus Tribolium (Poaceae: Arundineae). American Journal of Botany 79: 689-700.

SPIES, J.J. \& DU PLESSIS, H. 1986. Chromosome studies on African plants. 1. Bothalia 16:87, 88 .

SPIES, J.J. \& DU PLESSIS, H. 1988. Chromosome studies on African plants. 6. Bothalia 18: 111-123.

SPIES, J.J., DU PLESSIS, H., BARKER, N.P. \& VAN WYK, S.M.C. 1990. Cytogenetic studies in the genus Chaetobromus (Poaceae: Arundineae). Genome 33: 646-658.

SPIES, J.J., LINDER, H.P., LABUSCHAGNE, I.F. \& DU PLESSIS, H 1994. Cytogenetic evidence for the species delimitation of Pentaschistis airoides and $P$. patula (Poaceae: Arundineae) Proceedings from the XIIIth Plenary Meeting of AETFAT, Zomba, Malawi 1: 373-383.

SPIES, JJ. \& ROODT, R. 2001. The basic chromosome number of the genus Pentameris (Poaceae: Arundinoideae). Bothalia 31: 145, 146.

SPIES, J J SPIES, S.K, VAN WYK, S.M.C., MALAN, A.F. \& LIEBENBERG, E.J.L. 1996. Cytogenetic studies of the subfamily Pooideae
(Poaceae) in South Africa. 1. The tribe Aveneae, subtribe Aveninae. Bothalia 26: 53-61.

SPIES, J.J. \& VAN WYK, S.M.C. 1995. Cell fusion: a possible mechanism for the origin of polyploidy. South African Journal of Botany 61: 60-65.

VERBOOM, G.A. \& LINDER, H.P. 1998. A re-evaluation of species limits in Chaetobromus (Danthonieae: Poaceae). Nordic Journal of Botany 18: $57-77$.

VISSER, N.C. \& SPIES, J.J. 1994a. Cytogenetic studies in the genus Tribolium (Poaceae: Danthonieae). II. A report on embryo sac development, with special reference to the occurrence of apomixis in diploid specimens. South African Journal of Botany 60: 22-26.

VISSER, N.C \& SPIES, J.J. 1994b. Cytogenetic studies in the genus Tribolium (Poaceae: Danthonieae). III. Section Tribolium. South African Journal of Botany 60: 31-39.

VISSER, N.C. \& SPIES, J.J. 1994c. Cytogenetic studies in the genus Tribolium (Poaceae: Danthonieae). I. A taxonomical overview. South African Journal of Botany 60: 127-131.

VISSER, N.C. \& SPIES, J.J. 1994d. Cytogenetic studies in the genus Tribolium (Poaceae: Danthonieae). IV. Section Uniolae. South African Journal of Botany 60: 279-284.

VISSER, N.C. \& SPIES, J.J. 1994e. Cytogenetic studies in the genus Tribolium (Poaceae: Danthonieae). V. Section Acutiflorae, related genera, and conclusions. South African Journal of Botany 60: 285-292.

R. ROODT*, J.J. SPIES*, A.F. MALAN*, F. HOLDER* and S.M.C. VAN WYK*

* Department of Plant Sciences: Genetics (62), University of the Free State, P.O. Box 339, 9300 Bloemfontein.

MS, received: 2002-02-27.

\section{CHROMOSOME STUDIES ON AFRICAN PLANTS. 18. THE SUBFAMILY CHLORIDOIDEAE}

The subfamily Chloridoideae comprises \pm 150 genera and 1360 species and occurs mainly in arid regions (Hilu \& Alice 2001). The plants probably originated in Africa (Hartley 1964), hence the great representation of the subfamily in Africa and especially southern Africa, with \pm 51 genera and 235 species (Gibbs Russell et al. 1990). It is currently divided into five tribes by the Grass Phylogeny Working Group (GPWG 2001): Cynodonteae Dumort., Eragrostideae Stapf, Leptureae Dumort., Orcuttieae Reeder and Pappophoreae Kunth. The genus Centropodia Reich. and the species Merxmuellera rangei (Pilg.) Conert, previously included in the Arundinoideae, are now included in the Chloridoideae. They have not previously been included in any of the recognized tribes (GPWG 2001).

The aim of this study is to investigate chromosome numbers, meiotic chromosome behaviour and polyploid levels of some southern African representatives of this subfamily.

\section{MATERIALS AND METHODS}

Cytogenetic material of identical plants of a population was collected and fixed in the field. Voucher specimens, listed in Table 3, are housed in the Geo Potts Herbarium, Department of Plant Sciences, University of the Free State, Bloemfontein (BLFU), or in the National Herbarium, Pretoria (PRE).

Anthers were squashed in aceto-carmine and meiotically analysed (Spies et al. 1996) -at least 20 cells per meiot- ic stage were studied. Only gametic chromosome numbers are presented to conform to previous papers on chromosome numbers in this journal (Spies \& Du Plessis 1986)

\section{RESULTS AND DISCUSSION}

Seventy-nine plants, representing 42 species and 19 genera, were studied (Table 3). They represent three of the recognized tribes, namely Cynodonteae, Eragrostideae and Pappophoreae, as well as the unplaced genus Centropodia.

\section{Tribe Cynodonteae}

In the genus Chloris $\mathrm{Sw}$., a single $C$. virgata specimen was investigated and found to be diploid $(\mathrm{n}=\mathrm{x}=10)$

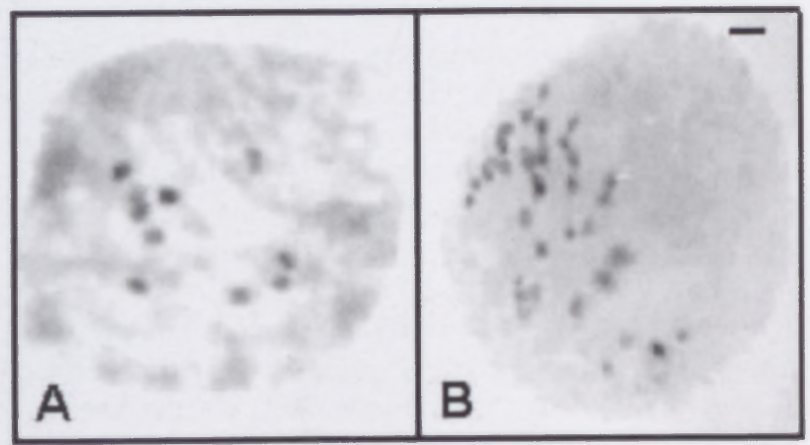

FIGURE 5.-Meiotic chromosomes. A, Chloris virgata, Spies 6616 , $2 \mathrm{n}=2 \mathrm{x}=20$, diakineses with 20 $;$ B, Cynodon dactylon, Spies $2549,2 \mathrm{n}=4 \mathrm{x}=36$, metaphase I. Scale bar: $5 \mu \mathrm{m}$. 
TABLE 1.-Gametic chromosome numbers ( $\mathrm{n}$ ) of representatives of subfamily Chloridoideae (Poaceae) in southern Africa with their voucher specimen numbers and specific localities. Species listed alphabetically and localities presented according to Edwards \& Leistner (1971)

\begin{tabular}{|c|c|c|c|}
\hline Taxon & $\mathrm{n}$ & Voucher & Locality \\
\hline \multicolumn{4}{|l|}{ Cynodonteae } \\
\hline Chloris virgata $\mathrm{Sw}$. & 10 & Spies 6616 & FREE STATE.—2827 (Senekal): $20 \mathrm{~km}$ from Senekal to Rosendal. (-BD). \\
\hline \multirow[t]{2}{*}{ Cynodon dactylon (L.) Pers. } & 18 & Spies 2549 & SWAZILAND_-2631 (Mbabane): $18 \mathrm{~km}$ northeast of Mbabane. (-AC). \\
\hline & 18 & Spies 2966 & NORTHERN CAPE.-2816 (Oranjemund): Alexander Bay. (-DA). \\
\hline $\begin{array}{l}\text { Enteropogon macrostachyus } \\
\text { (A.Rich.) Benth. }\end{array}$ & 10 & Venter 9339 & NAMIBIA_-1913 (Sesfontein): Sesfontein, Kaokoland, (-BB). \\
\hline \multirow[t]{12}{*}{ Harpochloa falx (L.f.) Kuntze } & 18 & Spies 5113 & MPUMALANGA.-2530 (Lydenburg): $5 \mathrm{~km}$ from Belfast to Dullstroom, (-CA). \\
\hline & 18 & Spies 5065 & $\begin{array}{l}\text { FREE STATE - } 2729 \text { (Volksrust): } 92 \mathrm{~km} \text { from Harrismith to Normandien Pass, } \\
(-D C) \text {. }\end{array}$ \\
\hline & 18 & Spies 5078 & $\begin{array}{l}\text { FREE STATE_- } 2729 \text { (Volksrust): } 97 \text { km from Harrismith to Normandien Pass, } \\
(-D C) \text {. }\end{array}$ \\
\hline & 18 & Spies 6629 & FREE STATE .-2827 (Senekal): 33 km from Senekal to Rosendal, (-BD). \\
\hline & 18 & Spies 3986 & EASTERN CAPE. - 3027 (Lady Grey): $45 \mathrm{~km}$ from Barkly East to Rhodes, (-DD). \\
\hline & 18 & Spies 4729 & $\begin{array}{l}\text { EASTERN CAPE.-3027 (Lady Grey): } 52 \text { km from Rhodes via Lundean's } \\
\text { Neck. (-DD). }\end{array}$ \\
\hline & 18 & Spies 4691 & $\begin{array}{l}\text { EASTERN CAPE. - } 3027 \text { (Lady Grey): } 47 \text { km from Rhodes via Naude's Neck. } \\
(-C C) \text {. }\end{array}$ \\
\hline & 18 & Spies 4695 & $\begin{array}{l}\text { EASTERN CAPE.-3027 (Lady Grey): } 65 \text { km from Rhodes to Maclear via } \\
\text { Naude's Neck. (-CC). }\end{array}$ \\
\hline & 18 & Spies 6955 & EASTERN CAPE.-3027 (Lady Grey): $39 \mathrm{~km}$ from Barkly Eas to Rhodes, (-DD). \\
\hline & 27 & Spies 5125 & $\begin{array}{l}\text { MPUMALANGA.- } 2530 \text { (Lydenburg): } 16 \mathrm{~km} \text { from Dullstroom to Lydenburg } \\
\text { via Frischgewaagd, (-AC). }\end{array}$ \\
\hline & 27 & Spies 5128 & $\begin{array}{l}\text { MPUMALANGA.-2530 (Lydenburg): Nederhorst turn-off on Lydenburg- } \\
\text { Roossenekal road, (-AA). }\end{array}$ \\
\hline & 27 & Spies 4712 & EASTERN CAPE.-3128 (Umtata): 38 km from Maclear to Elliott. (-AC). \\
\hline Tragus sp. & 10 & Spies 4803 & FREE STATE_-2827 (Senekal): $6 \mathrm{~km}$ from Clocolan to Peka bridge. (-DC). \\
\hline \multicolumn{4}{|l|}{ Eragrostideae } \\
\hline Bew'sia biflora (Hack.) Gooss. & 20 & Spies 1531 & MPUMALANGA.-2530 (Lydenburg): Steenkampsberg. (-AA). \\
\hline \multirow[t]{4}{*}{$\begin{array}{l}\text { Cladoraphis cyperoides (Thunb.) } \\
\text { S.M.Phillips }\end{array}$} & 10 & Spies 5704 & $\begin{array}{l}\text { NORTHERN CAPE - }-2816 \text { (Oranjemund): } 46 \mathrm{~km} \text { from Bloeddrift to Alexander } \\
\text { Bay, }(-C B) \text {. }\end{array}$ \\
\hline & 10 & Spies 4894 & $\begin{array}{l}\text { NORTHERN CAPE.-2917 (Springbok): } 135 \text { km from Springbok to Kleinsee. } \\
\text { (-CA). }\end{array}$ \\
\hline & 10 & Spies 4889 & $\begin{array}{l}\text { NORTHERN CAPE._-2917 (Springbok): } 84 \text { km from Springbok to Kleinsee. } \\
(- \text { CA). }\end{array}$ \\
\hline & 10 & Spies 5356 & $\begin{array}{l}\text { WESTERN CAPE.-3118 (Vanrhynsdorp): } 21 \mathrm{~km} \text { from Doorn Bay to Donkin } \\
\text { Bay, (-CD). }\end{array}$ \\
\hline C. spinosa (L.f.) S.M.Phillips & 20 & Spies 4885 & $\begin{array}{l}\text { NORTHERN CAPE. - } 2917 \text { (Springbok): } 82 \text { km from Springbok to Kleinsee, } \\
\text { (-CA). }\end{array}$ \\
\hline $\begin{array}{l}\text { Dactyloctenium aegyptium } \\
\text { (L.) Willd. }\end{array}$ & 20 & Spies 2403 & $\begin{array}{l}\text { KWAZULU-NATAL. - } 2832 \text { (Mtubatuba): } 22 \mathrm{~km} \text { from Cape Vidal to St Lucia. } \\
\text { (-AD). }\end{array}$ \\
\hline \multirow{2}{*}{$\begin{array}{l}\text { Eleusine coracana (L.) Gaertn. } \\
\text { subsp. africana (Kenn.- } \\
\text { O'Byrne) Hilu \& De Wet }\end{array}$} & 9 & Spies 2365, 2366 & KWAZULU-NATAL- - 2832 (Mtubatuba): Cape Vidal. (-BA). \\
\hline & 18 & Spies 2783 & WESTERN CAPE.-3118 (Vanthynsdorp): Koekenaap. irigation scheme. (-CB). \\
\hline Eragrostis barbinodis Hack. & 20 & Spies 3317 & NORTHERN PROVINCE-2428 (Nylstroom): Soutpan, (-CD). \\
\hline \multirow[t]{7}{*}{ E. capensis (Thunb.) Trin. } & 10 & Spies 4696 & $\begin{array}{l}\text { EASTERN CAPE. - } 3027 \text { (Lady Grey): } 65 \mathrm{~km} \text { from Rhodes via Naude's Neck. } \\
(-\mathrm{CC}) \text {. }\end{array}$ \\
\hline & 20 & Spies 1595 & $\begin{array}{l}\text { MPUMALANGA.-2530 (Lydenburg): } 41 \mathrm{~km} \text { from Lydenburg to Roossenekal. } \\
(-\mathrm{AB}) \text {. }\end{array}$ \\
\hline & 20 & Spies 5069 & $\begin{array}{l}\text { FREE STATE - } 2729 \text { (Volksrust): } 92 \mathrm{~km} \text { from Harrismith to Normandien Pass. } \\
(-D C) \text {. }\end{array}$ \\
\hline & 20 & Du Plessis 110 & KWAZULU-NATAL.-293! (Stanger): Balito Bay to Umhlali. (-AC). \\
\hline & 20 & Spies 3483 & $\begin{array}{l}\text { EASTERN CAPE. }-3325 \text { (Por Elizabeth): } 2 \mathrm{~km} \text { from Rocklands to Elands } \\
\text { River. (-CD). }\end{array}$ \\
\hline & 20 & Spies 3498 & $\begin{array}{l}\text { EASTERN CAPE- } 3424 \text { (Humansdorp): } 4 \mathrm{~km} \text { from Humansdorp to Cape St. } \\
\text { Francis, (-BB). }\end{array}$ \\
\hline & 20 & Davidse 33552 & Locality unknown. \\
\hline E. chloromelas Steud. & 20 & Spies 6947 & $\begin{array}{l}\text { EASTERN CAPE- - } 3027 \text { (Lady Grey): } 35 \mathrm{~km} \text { from Aliwal North to Lady Grey, } \\
\text { (-CA). }\end{array}$ \\
\hline E. ciliaris (L.) R.Br & 10 & Du Plessis III & KWAZULU-NATAL. - 2931 (Stanger): Balito Bay to Umhlali. (-AC). \\
\hline E. curvula (Schrad.) Nees & 30 & Spies 1137 & $\begin{array}{l}\text { EASTERN CAPE. - } 3225 \text { (Somerset East): } 35 \mathrm{~km} \text { from Somerset East to } \\
\text { Pearston. (-CB). }\end{array}$ \\
\hline E. echinochloidea Stapf & 20 & Spies 2799. 2800) & $\begin{array}{l}\text { NORTHERN CAPE }-3018 \text { (Kamiesberg): } 3 \mathrm{~km} \text { from Bitterfontein to Garies, } \\
(-D B) \text {. }\end{array}$ \\
\hline E. heteromera Stapf & 20 & Spies 2634 & SWAZILAND._2631 (Mbabane): $80 \mathrm{~km}$ from Manzini to Lomahasha. (-BA). \\
\hline E. inamoena K.Schum. & 20 & Spies 2392 & $\begin{array}{l}\text { KWAZULU-NATAL-2832 (Mtubatuba): } 12 \mathrm{~km} \text { from Cape Vidal to St Lucia. } \\
(-\mathrm{AD}) \text {. }\end{array}$ \\
\hline $\begin{array}{l}\text { E. obrusa Munro ex Ficalho } \\
\text { \& Hiern. }\end{array}$ & 10 & Spies 2886 & $\begin{array}{l}\text { NORTHERN CAPE.-2823 (Griekwastad): } 16 \mathrm{~km} \text { from Griekwastad to } \\
\text { Kimberley. (-CD). }\end{array}$ \\
\hline E. planiculmis Nees & 30 & Spies 1116 & $\begin{array}{l}\text { EASTERN CAPE.-3225 (Somerset East): Daggahoersnek Pass. Cookhouse } \\
\text { to Cradock. (-DB). }\end{array}$ \\
\hline E. racemosa (Thunb.) Steud. & 20 & Spies 50k6 & $\begin{array}{l}\text { FREE STATE }-2729 \text { (Volksnust): } 92 \mathrm{~km} \text { from Harrismith to Normandien Pass. } \\
(-D C) \text {. }\end{array}$ \\
\hline
\end{tabular}


TABLE 1.-Gametic chromosome numbers ( $\mathrm{n}$ ) of representatives of subfamily Chloridoideae (Poaceae) in southem Africa with their voucher specimen numbers and specific localities. Species listed alphabetically and localities presented according to Edwards \& Leistner (1971) (cont.)

\begin{tabular}{|c|c|c|c|}
\hline Taxon & $\mathrm{n}$ & Voucher & Locality \\
\hline \multirow[t]{2}{*}{ E. racemosa (Thunb.) Steud. } & 20 & Spies 3279 & KWAZULU-NATAL. - 2829 (Harrismith): Windy Corner, Van Reenen, (-AD). \\
\hline & 20 & Spies 4743 & $\begin{array}{l}\text { EASTERN CAPE. - } 3027 \text { (Lady Grey): } 15 \text { km from Barkly East to Lady Grey, } \\
\text { (-CD). }\end{array}$ \\
\hline $\begin{array}{l}\text { E. sclerantha Nees subsp. } \\
\text { sclerantha }\end{array}$ & 20 & Spies 4844 & FREE STATE. - 2828 (Bethlehem): $19 \mathrm{~km}$ from Fouriesburg to Clarens, (-CA). \\
\hline \multirow{2}{*}{ E. superba Peyr. } & 20 & Spies 3326 & NORTHERN PROVINCE. - 2428 (Nylstroom): Soutpan, (-CD). \\
\hline & 20 & Du Plessis 136 & KWAZULU-NATAL.-2830 (Dundee): $5 \mathrm{~km}$ from Muden to Greytown. (-DC). \\
\hline E. tef (Zucc.) Trotter & 20 & Spies 2405 & $\begin{array}{l}\text { KWAZULU-NATAL. - } 2832 \text { (Mtubatuba): } 22 \mathrm{~km} \text { from Cape Vidal to Si Lucia. } \\
\text { (-AD). }\end{array}$ \\
\hline E. tenuifolia (A.Rich.) Steud. & 10 & Spies 2595 & SWAZILAND.-2631 (Mbabane): Siteki, (-BD). \\
\hline E. trichophora Coss. \& Dur. & 20 & Spies 2774 & $\begin{array}{l}\text { WESTERN CAPE.-3118 (Vanrhynsdorp): } 3 \mathrm{~km} \text { from Lutzville to Koekenaap, } \\
(-\mathrm{CB}) \text {. }\end{array}$ \\
\hline \multirow[t]{2}{*}{ Fingerhuthia africana Lehm. } & 20 & Spies 2947 & NAMIBIA. - 2618 (Keetmanshoop): Remshoogte, Annisfontein. (-BD). \\
\hline & 20 & Spies 4349 & $\begin{array}{l}\text { WESTERN CAPE.-3118 (Vanrhynsdorp): } 35 \mathrm{~km} \text { from Vanrhynsdorp to Nieu- } \\
\text { woudtville, (-DA). }\end{array}$ \\
\hline \multirow[t]{8}{*}{ Leptochloa fusca (L.) Kunth. } & 10 & Spies 4875 & NORTHERN CAPE_-2917 (Springbok): 7 km from Springbok to Kleinsee, (-DB). \\
\hline & 10 & Spies 2991A & NORTHERN CAPE. - 3017 (Hondeklipbaai): $5 \mathrm{~km}$ east of Kamieskroon, (-BB). \\
\hline & 10 & Spies 3037 & NORTHERN CAPE_-3017 (Hondeklipbaai): 12 km east of Hondeklipbaai. (-AD). \\
\hline & 10 & Spies 4316 & $\begin{array}{l}\text { NORTHERN CAPE.-3018 (Kamiesberg): } 35 \mathrm{~km} \text { from Leliefontein to Garies, } \\
(-\mathrm{AB}) \text {. }\end{array}$ \\
\hline & 10 & Spies 3794 & WESTERN CAPE.-3118 (Vanrhynsdorp): Gifberg. (-CB). \\
\hline & 10 & Spies 5200 & $\begin{array}{l}\text { WESTERN CAPE. - } 3324 \text { (Steytlerville): } 34 \mathrm{~km} \text { from Patensie to Willowmore, } \\
\text { (-DD). }\end{array}$ \\
\hline & 10 & Spies 3932 & $\begin{array}{l}\text { WESTERN CAPE-_3419 (Caledon): McGregor FM tower, Riviersonderend } \\
\text { Mountain, (-BA). }\end{array}$ \\
\hline & 10 & Davidse 33407 & Locality unknown. \\
\hline Odyssea paucinervis (Nees) Stapf & 18 & Spies 3384 & NORTHERN CAPE.-3017 (Hondeklipbaai): Groen River mouth, (-DC). \\
\hline \multirow[t]{2}{*}{$\begin{array}{l}\text { Sporobolus africanus (Poir.) } \\
\text { Robyns \& Tournay }\end{array}$} & 9 & Spies 4508 & $\begin{array}{l}\text { WESTERN CAPE_- } 3420 \text { (Bredasdorp): } 1.4 \text { km from De Hoop Nature Reserve. } \\
\text { (-AD). }\end{array}$ \\
\hline & 18 & Spies 2369 & KWAZULU-NATAL.-2832 (Mtubatuba): Cape Vidal. (-BA). \\
\hline S. albicans Nees & 27 & Spies 3141 & $\begin{array}{l}\text { WESTERN CAPE.-3220 (Sutherland): } 15 \mathrm{~km} \text { from Sutherland to Matjiesfontein. } \\
\text { Verlatenkloof, }(-\mathrm{BC}) \text {. }\end{array}$ \\
\hline S. ioclados (Trin.) Nees & 9 & Spies 3171 & WESTERN CAPE.-3218 (Clanwilliam): $1 \mathrm{~km}$ from Sauer to Velddrif. (-DC). \\
\hline S. virginicus (L.) Kunth & 9 & Du Plessis 122 & $\begin{array}{l}\text { KWAZULU-NATAL.-293I (Stanger): Tongaat River, on beach near bridge, } \\
\text { (-CA). }\end{array}$ \\
\hline $\begin{array}{l}\text { Stiburus alopecuroides (Hack.) } \\
\text { Stapf }\end{array}$ & 10 & Spies 1470 & $\begin{array}{l}\text { MPUMALANGA-2530 (Lydenburg): Steenkampsberg, } 18 \mathrm{~km} \text { from Dullstroom } \\
\text { to Goede Hoop, }(-\mathrm{AC}) \text {. }\end{array}$ \\
\hline S. conrathii Hack. & 10 & Du Plessis 19 & $\begin{array}{l}\text { MPUMALANGA.-2530 (Lydenburg): } 19 \mathrm{~km} \text { from Lydenburg to Weltevreden, } \\
(-\mathrm{AB}) \text {. }\end{array}$ \\
\hline Trichoneura sp. & 10 & Spies 4833 & $\begin{array}{l}\text { FREE STATE-_ } 2827 \text { (Senekal): } 6 \mathrm{~km} \text { from Nebo to Fouriesburg via Generaals- } \\
\text { nek. (-DB). }\end{array}$ \\
\hline \multicolumn{4}{|l|}{ Pappophoreae } \\
\hline \multirow{2}{*}{$\begin{array}{l}\text { Enneapogon cenchroides } \\
\quad \text { (Roem. \& Schult.) C.E.Hubb. }\end{array}$} & 20 & Spies 3288 & NORTHERN PROVINCE. - 2428 (Nylstroom): Soutpan at the crater, (-CD). \\
\hline & 30 & Spies 2709 & $\begin{array}{l}\text { NORTHERN CAPE.-2924 (Hopetown): } 31 \mathrm{~km} \text { from Hopetown to Britstown. } \\
\text { (-CA). }\end{array}$ \\
\hline E. pretoriensis Stent & 10 & Spies 3716 & $\begin{array}{l}\text { NORTH-WEST.-2527 (Rustenburg): } 7 \mathrm{~km} \text { from Hartbeeshoek turn-off } \\
\text { between Muldersdrift and Hekpoort. (-DB). }\end{array}$ \\
\hline Enneapogon sp. & 20 & Spies 5532 & $\begin{array}{l}\text { NORTH-WEST.-2725 (Bloemhof): } 31 \mathrm{~km} \text { from Vryburg to Schweizer-Reineke. } \\
\text { (-AB). }\end{array}$ \\
\hline $\begin{array}{l}\text { Schmidtia pappophoroides. } \\
\text { Steud }\end{array}$ & 18 & Du Plessis 186 & $\begin{array}{l}\text { NORTHERN PROVINCE.-2329 (Pietersburg): } 66 \mathrm{~km} \text { from Pietersburg to } \\
\text { Louis Trichardt. (-BB). }\end{array}$ \\
\hline Schmidtia sp. & $18+0-4 B$ & Spies 5536 & NORTH-WEST.-2624 (Vryburg): 36 km from Vryburg to Amalia. (-DC). \\
\hline \multicolumn{4}{|l|}{ Unplaced } \\
\hline $\begin{array}{l}\text { Centropodia glauca (Nees) } \\
\text { Cope }\end{array}$ & 24 & Spies 5706 & $\begin{array}{l}\text { NORTHERN CAPE.-2816 (Oranjemund): } 46 \mathrm{~km} \text { from Blceddrift to Alexander } \\
\text { Bay, (-DA). }\end{array}$ \\
\hline
\end{tabular}

(Figure 5A). This confirms the basic chromosome number of 10 for this genus (Darlington \& Wylie 1955; Pienaar 1955; Ornduff 1967, 1968, 1969; Federov 1969; Moore 1970, 1971, 1972, 1973, 1974, 1977; Goldblatt 1981, 1983, 1985, 1988; Goldblatt \& Johnson 1990. 1991, 1998, 2000). Polyploid levels do occur in the genus and triploid and tetraploid numbers have been observed in South African specimens by previous authors (Moffet \& Hurcombe 1949; De Wet 1954; Spies \& Du Plessis 1987). The genus is known to contain many aneuploid deviations from the basic chromosome number of ten (Fish 2000), but none have been observed in
South African specimens before (Hunter 1934; Moffet \& Hurcombe 1949; De Wet 1954; Spies \& Du Plessis 1987: Spies \& Jonker 1987; Strydom \& Spies 1994).

Cynodon dactylon is an introduced species in tropical and warm temperate areas throughout the world, but is indigenous to southern Africa (Gibbs Russell \& Spies 1988). Two specimens were investigated, both with $2 n=4 x=36$ (Figure 5B). Tetraploidy is by far the most numerous polyploid level present in the genus (Darlington \& Wylie 1955; Pienaar 1955; Ornduff 1968, 1969; Federov 1969: Moore 1970, 1972, 1973, 1974, 1977; Goldblatt 


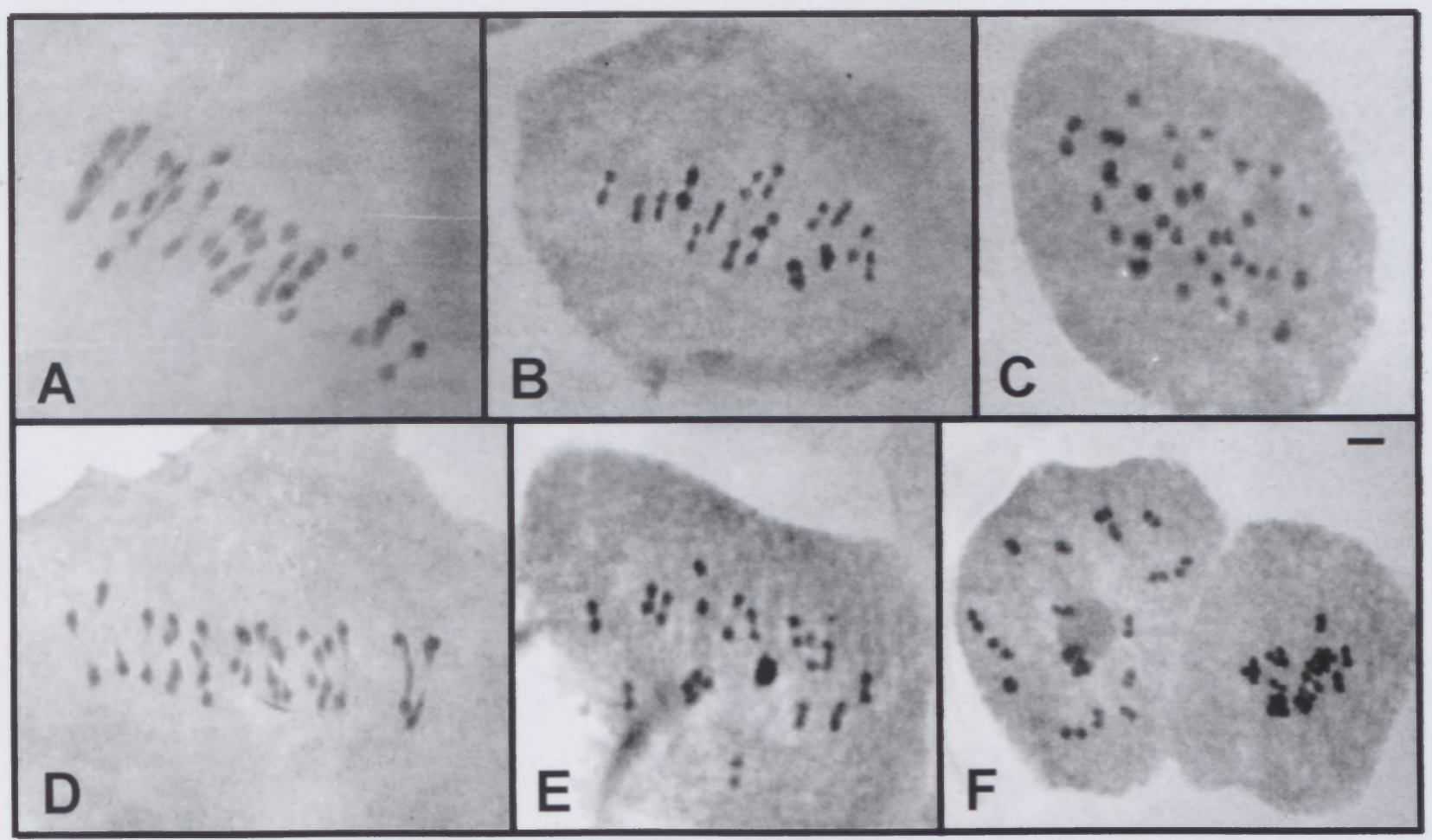

FIGURE 6.-Meiotic chromosomes in Harpochloa falx. A, Spies 3986, $2 \mathrm{n}=4 \mathrm{x}=36$, metaphase I. B, C, Spies 4695, $2 \mathrm{n}=4 \mathrm{x}=36$ : B, metaphase I; C, desynapsis of bivalents during metaphase I. D, Spies $4729,2 \mathrm{n}=4 \mathrm{x}=36$, metaphase I; E, Spies $5113,2 \mathrm{n}=4 \mathrm{x}=36$, metaphase I; F, Spies $6955,2 \mathrm{n}=4 \mathrm{x}=36$, diakineses with $18_{\mathrm{II}}$. Scale bar: C, E, $8 \mu \mathrm{m} ; \mathrm{A}, \mathrm{B}, \mathrm{D}, \mathrm{F}, 10 \mu \mathrm{m}$.

1981, 1983, 1985; Goldblatt \& Johnson 1990, 1994, 1996, 1998). De Silva \& Snaydon (1995) concluded that the differences in the polyploid level in $C$. dactylon could be related both to different climatic regions and different ecological habitats. The populations growing in arid, dry and intermediate regions were tetraploid and those from wetter regions consisted entirely of diploid plants. De Silva \& Snaydon (1995) also related these polyploid levels to soil acidity and alkalinity (tetraploid $=\mathrm{pH}>6.5$; diploid $=\mathrm{pH}$ $<5.0$ ). These findings might explain the predominance of tetraploidy in South Africa with its dryer, more arid regions. A basic chromosome number of $x=9$ is confirmed for this species and genus, although 10 has also been reported in a few instances (Ornduff 1968, 1969; Moore 1970, 1972, 1974, 1977; Goldblatt 1981, 1983, 1985; Goldblatt \& Johnson 1990, 1994, 1996, 1998).

Chromosome numbers for the genus Enteropogon Nees have only been reported once and a basic chromosome number of 10 published for the genus (Darlington \& Wylie 1955). One E. macrostachyus specimen investigated in this study was found to be tetraploid $(\mathrm{n}=2 \mathrm{x}=$ 20). This is the first report on a South African specimen in the genus, the previous one being from India.

Twelve specimens representing the species Harpochloa falx were studied. Nine of these were tetraploid and three were hexaploid. All specimens had multiples of nine $(n=2 x=18 ; n=3 x=54)$ (Figure 6A-F). This represents a new basic chromosome number for this genus and could imply that Harpochloa also has two basic chromosome numbers (De Wet 1958; Spies \& Du Plessis 1986; Spies et al. 1991; Strydom \& Spies 1994). Furthermore, no known reports of any diploid specimens in the genus exist, which could indicate the existence of an older polyploid complex.
The genus Tragus Haller is widespread throughout the tropics, but mainly in Africa. It is especially common in disturbed areas (Clayton \& Renvoize 1986; Fish 2000). One Tragus specimen was investigated and found to be diploid with $\mathrm{n}=\mathrm{x}=10$. Only diploid, as in this study, or tetraploid chromosome numbers are known for this genus, based on a basic chromosome number of 10 (Darlington \& Wylie 1955; Ornduff 1967, 1968, 1969; Federov 1969; Moore 1970, 1972, 1973, 1974, 1977; Goldblatt 1981, 1983, 1988; Goldblatt \& Johnson 1990, 1994, 1998).

\section{Tribe Eragrostideae}

The genus Bewsia Gooss. is monotypic and a single Bewsia biflora specimen was investigated. This specimen was tetraploid $(n=2 x=20)$ (Figure $7 A)$, which confirms a basic chromosome number of ten, based on previous reports by De Wet \& Anderson (1956) of $2 \mathrm{n}=$ $3 \mathrm{x}=30$ and Davidse et al. (1986) of $2 \mathrm{n}=45$ from Zimbabwe. Davidse et al. (1986) reported on very irregular meiosis in the particular specimen. Results presented in this study are the third known report for this genus.

Cladoraphis Franch. comprises two species $C$. cyperoides and C. spinosa. De Winter (1955) included this genus in Eragrostis Wolf, but later authors (Phillips 1982; Clayton \& Renvoize 1986; Gibbs Russell et al. 1990; Watson \& Dallwitz 1992) retained its separate generic status. It has a very specific habitat and occurs in sandy desert ( $C$. spinosa) and coastal dunes ( $C$. cyperoides) (Clayton \& Renvoize 1986), mainly in the western regions of Namibia and Northern and Western Cape (Fish 2000). Five specimens were investigated representing both species. All four $C$. cyperoides specimens were diploid, with $C$. spinosa being tetraploid $(\mathrm{n}=2 \mathrm{x}=20)$ 


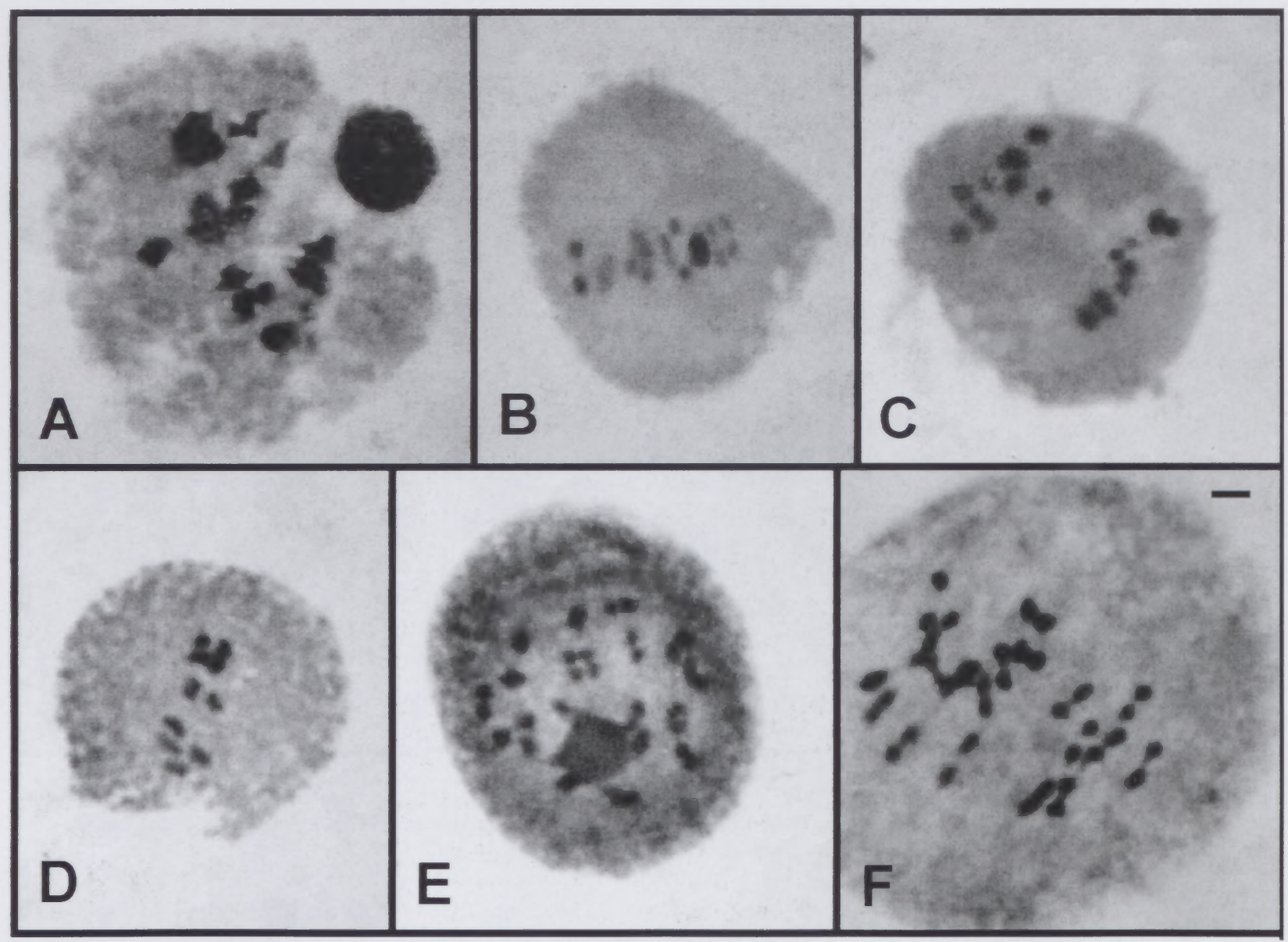

FIGURE 7.-Meiotic chromosomes. A, Bewsia biflora, Spies $1531,2 \mathrm{n}=4 \mathrm{x}=40$, diakineses with $20 \mathrm{n}$, three chromosomes are not in focus on this photograph. B, C, Cladoraphis cyperoides, Spies 4894, $2 \mathrm{n}=2 \mathrm{x}=20$ : B, metaphase I; C, anaphase I, 10-10 segregation. D, C. cyperoides, Spies 5356, $2 \mathrm{n}=2 \mathrm{x}=20$, diakinesis; E, C. spinosa, Spies $4885,2 \mathrm{n}=4 \mathrm{x}=40$, diakineses with $20_{\| 1} ; \mathrm{F}$, Dactyloctenium aegyptium, Spies $2403,2 n=4 x=40$, metaphase I. Scale bar: $5 \mu \mathrm{m}$.

(Figure 7B-E). This is, to the best of our knowledge, the first reports for chromosome numbers in this genus.

One specimen of the widespread tropical weed (Gould \& Soderstrom 1974) Dactyloctenium aegyptium was investigated. It was found to be tetraploid $(\mathrm{n}=2 \mathrm{x}=20)$ (Figure $7 \mathrm{~F}$ ). Three basic chromosome numbers are recorded for this genus, $x=9,10,12$ (Darlington \& Wylie $1955(\mathrm{x}=10,12)$; Pienaar 1955 $(\mathrm{x}=9,12)$; Ornduff $1967(\mathrm{x}=10), 1968(\mathrm{x}=12)$; Moore $1971(x=9), 1972(x=9), 1977(x=12)$; Goldblatt 1981 $(\mathrm{x}=9,10,12), 1983(\mathrm{x}=9,10,12), 1985(\mathrm{x}=12), 1988$ $(\mathrm{x}=9,10)$; Goldblatt \& Johnson $1990(\mathrm{x}=9,10,12)$, $1991(\mathrm{x}=10), 1994(\mathrm{x}=12), 1998(\mathrm{x}=10,12)$. This is one of the genera in the Chloridoideae (as is Sporobolus), with the most variation in basic chromosome number.

The generic status of Diplachne P.Beauv. has long been in doubt (McVaugh 1983; Peterson et al. 1997), with some authors preferring to unite this genus with the closely related genus Leptochloa P.Beauv. (McNeill 1979; Phillips 1982). These two genera have traditionally been kept distinct by Old World taxonomists where these genera are quite distinct, whereas the position of the genera from the Americas are very confused with intergrading taking place (Phillips 1982). For this study, the accepted name Leptochloa will be used.
Eight Leptochloa fusca specimens were investigated and all were diploid $(\mathrm{n}=\mathrm{x}=10)$ (Figure $8 \mathrm{~A}-\mathrm{E})$, which confirms the basic chromosome number of ten for this genus (Darlington \& Wylie 1955; Ornduff 1968; Federov 1969; Moore 1977; Goldblatt \& Johnson 1990, 1991, 1994, 1998). Previous studies have mostly reported tetraploids and this is the first study with such a large number of diploids. The specimens investigated were largely from Northern and Western Cape, and due to the widespread distribution of this species, the total variation present might not be represented.

Eleusine Gaertn. is predominantly an African genus, with six of the nine species confined to tropical and subtropical Africa (Phillips 1972). Eleusine coracana (L.) Gaertn. is widely grown in Africa, India and China, and used as a cereal. It is derived from $E$. indica (L.) Gaertn., a diploid cosmopolitan weed (subsp. indica, $2 \mathrm{n}=18$ ), which has a tetraploid race in Africa (subsp. africana). The morphological characters of the two races overlap greatly, and this leads to their inclusion in a single species (Clayton \& Renvoize 1986). Eleusine coracana subsp. africana $(=E$. indica subsp. africana) is native to Africa, where it is widespread along the eastern highlands and the highlands of the southern African plateau (Phillips 1972).

Three $E$. coracana subsp. africana specimens were investigated. The two specimens from Cape Vidal were 


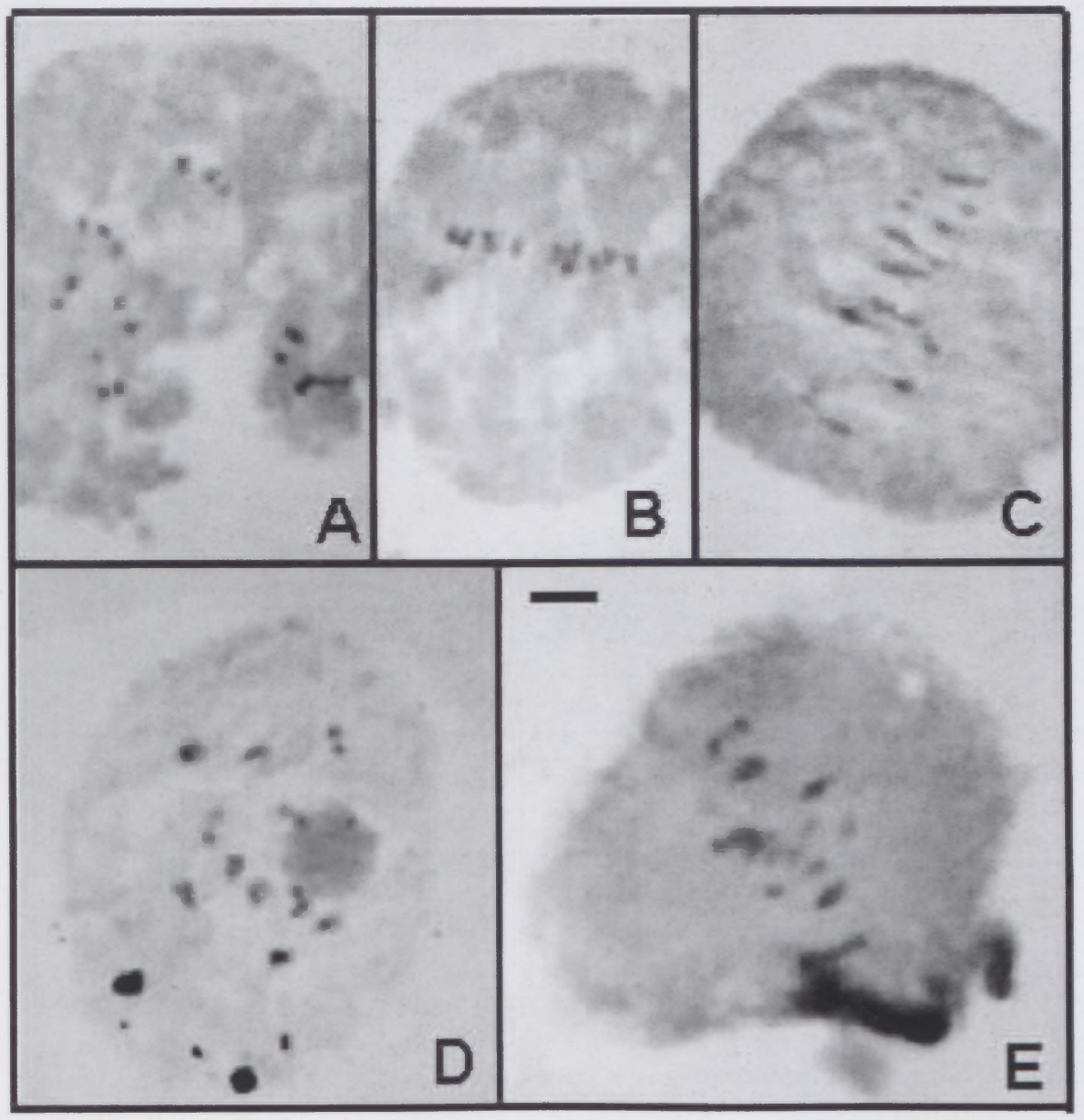

FIGURE 8.-Meiotic chromosomes in Leptochloa fusca. A, B, Spies 3794, $2 n=2 x=20$ : A, anaphase I with 10 -10 segregation; B, metaphase I. C, Spies $3932,2 \mathrm{n}=2 \mathrm{x}=20$, metaphase I; D, Spies $4316,2 \mathrm{n}=2 \mathrm{x}=20$. diakineses with $10_{\| l} ; \mathrm{E}$, Spies $5200,2 \mathrm{n}=2 \mathrm{x}=20$, metaphase I. Scale bar: $5 \mu \mathrm{m}$.

diploid (Figure 9A, B) and the specimen from Koekenaap in Western Cape was tetraploid $(n=2 x=18)$ (Figure 9C). This indicates that diploid and tetraploid forms of this species are present in South Africa and confirm a basic chromosome number of nine for this genus (Darlington \& Wylie 1955; Pienaar 1955; Ornduff 1967, 1968, 1969; Federov 1969; Moore 1970, 1971, 1972, 1974, 1977; Goldblatt 1981, 1983, 1985, 1988; Goldblatt \& Johnson 1990, 1991, 1994, 1998, 2000).

Eragrostis Wolf is the largest genus in the subfamily Chloridoideae. It has a worldwide occurrence in the warmer regions where it is found in most habitats, showing a preference for open sites, poor dry soil and weedy places (Clayton \& Renvoize 1986). The genus exhibits the full range of morphological and anatomical variation found in the subfamily (Van den Borre \& Watson 1994).

Eragrostis is the largest grass genus in southern Africa with \pm 90 species. In this study 27 specimens were investigated, representing 17 species. Twenty of the specimens were tetraploid (Figure 10E, F, H). Only five specimens investigated were diploid and two were hexaploid (Figure 10D, G). Polyploidy is frequent in this genus as can be seen from the results presented. Tetraploidy, as in this study, is the most frequent polyploid level observed, followed by diploidy (Darlington \& Wylie 1955; Pienaar 1955; Ornduff 1967, 1968, 1969; Moore 1970, 1971, 1972, 1973, 1974, 1977; Goldblatt 1981, 1983, 1985, 1988; Goldblatt \& Johnson 1990 , 1991, 1994, 1998, 2000).

Seven specimens were investigated for $E$. capensis. All but one was tetraploid (Figure 10A-C). Spies 4696 was diploid and is the second report for this species (De Wet 1958) where tetraploidy (Avdulov 1931; Pienaar 1953; Davidse et al. 1986; Spies \& Du Plessis 1986; Spies et al. 1991 ) and hexaploidy (Moffet \& Hurcombe 1949; Spies \& Voges 1988) have previously been observed.

De Winter (1955) regards $E$. curvula as the most variable species in the genus in southern Africa, with a great many morphological forms. This was corroborated by large-scale cytogenetic studies by Vorster \& Liebenberg

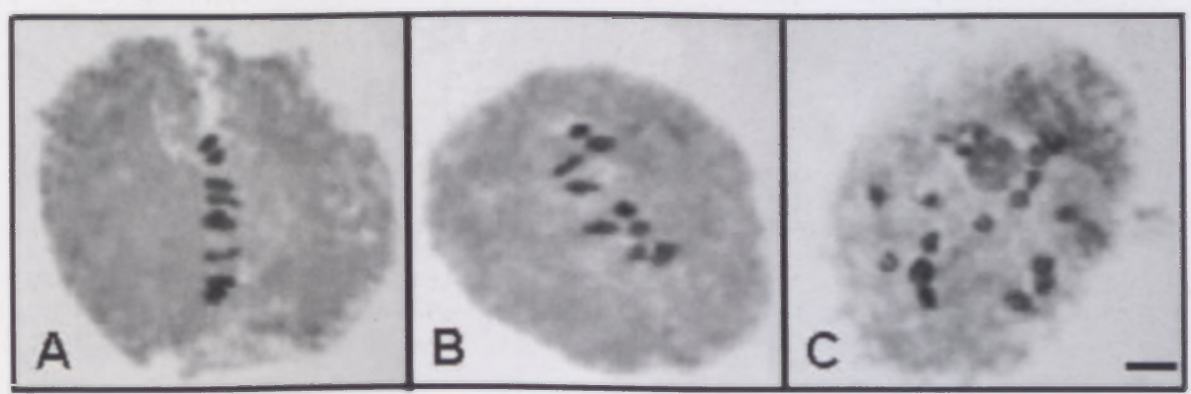

FIGURE 9.-Meiotic chromosomes in Eleusine coracana subsp. africana. A, B, Spies 2365, $2 \mathrm{n}=2 \mathrm{x}=18$, metaphase I; C, Spies $2783,2 \mathrm{n}=4 \mathrm{x}=36$, diakineses with $18_{\text {III }}$ Scale bar: $5 \mu \mathrm{m}$. 


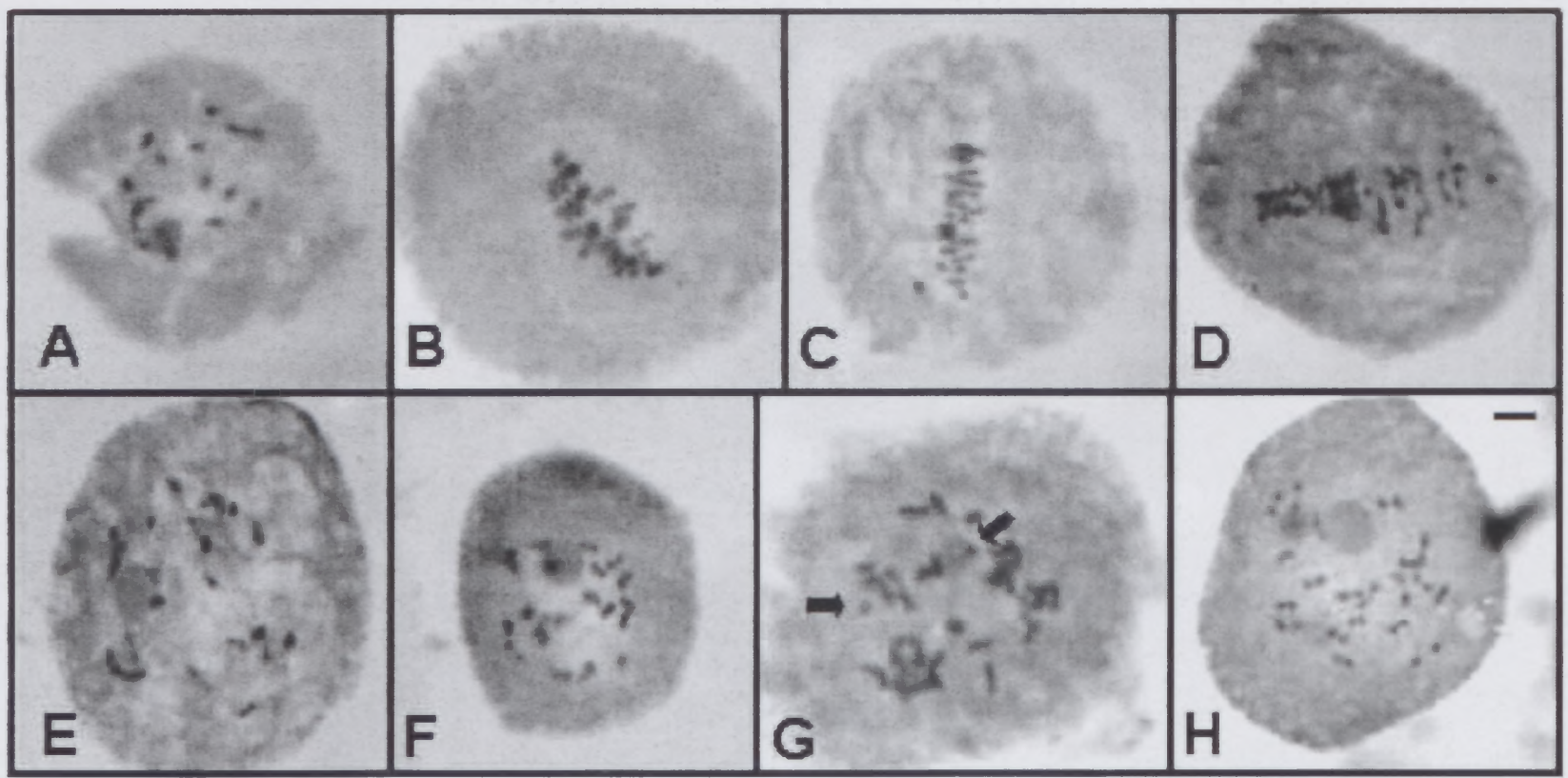

FIGURE 10.-Meiotic chromosomes. A-C, Eragrostis capensis: A, Spies 3483, $2 \mathrm{n}=4 \mathrm{x}=40$, diakineses with 20 metaphase I; C, Spies 5069, $2 \mathrm{n}=4 \mathrm{x}=40$, metaphase I. D, E. curvula, Spies 1137, $\mathrm{n}=6 \mathrm{x}=60 ; \mathrm{E}$, E. echinocloidea, Spies 2799, $2 \mathrm{n}=4 \mathrm{x}$ $=40$, diakineses with $20 \sharp ; \mathrm{F}$, E. inamoena, Spies 2392, $2 \mathrm{n}=4 \mathrm{x}=40$, diakineses with $20 \sharp ; \mathrm{G}$, E. planiculmis, Du Plessis $116,2 \mathrm{n}=6 \mathrm{x}=$ $60+0-4 \mathrm{~B}$, diakineses with $30_{\mathrm{u}}$, two B chromosomes are indicated; $\mathrm{H}, \mathrm{E}$. superba, Du Plessis $136,2 \mathrm{n}=4 \mathrm{x}=40$, diakineses with $20_{\|}$. Scale bar: B, G, $10 \mu \mathrm{m}$; A, C-F, H, $12 \mu \mathrm{m}$.

(1977). Several species are known to intergrade with $E$. curvula through hybridization: $E$. barbinodes, E. caesia Stapf, E. chloromelas, E. lehmaniana Nees, E. planiculmis and E. rigidor Pilg. (Smook 1990). Proof of hybridization in this species indicates a collapse of isolating mechanisms between different species in the Eragrostis curvula complex, resulting in a large-scale hybrid swarm, with continuous variation of characters between parental extremes. The variation in morphological characters is an indication of the extent of hybridization (Spies 1984). Four specimens in this complex were cytogenetically investigated and tetraploid $(E$. barbinodes and $E$. chloromelas) and hexaploid (E. curvula and $E$. planiculmis) levels were observed (Figure 10D, G). In all but $E$. barbinodes, various univalents were observed which resulted in laggards and later formed micronuclei. According to Church (1929), the presence of unpaired or univalent chromosomes is one of the most prominent suggestions that a plant is of hybrid origin (Church 1929) and therefore, in this complex with its large-scale hybridization, these phenomena will be very prevalent.

This is the third report for the species $E$. heteromera with $2 \mathrm{n}=4 \mathrm{x}=40$ (De Wet 1958; De Wet 1960). As far as is known only two reports for E. tef exist (Avdulov

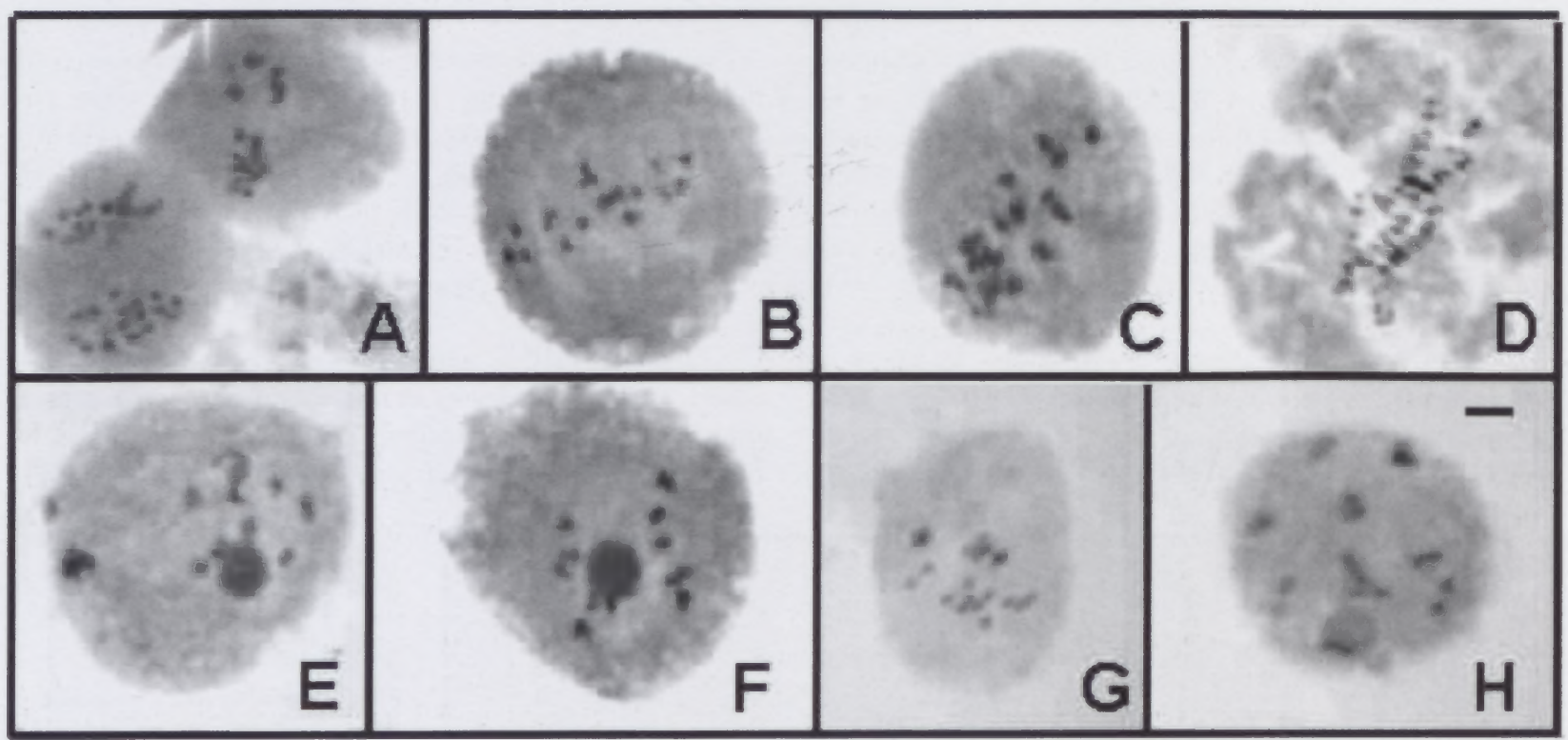

FIGURE 11.-Meiotic chromosomes. A, B, Fingerhuthia africana, Spies 2947, 2n = 4x = 40: A, late anaphase I; B, metaphase I. C, Sporobolus albicans, Spies $3141,2 \mathrm{n}=6 \mathrm{x}=54$, metaphase I; D, S. africanus, Spies $2369,2 \mathrm{n}=4 \mathrm{x}=36$, metaphase I; E, F, S. virginicus, Du Plessis $122,2 \mathrm{n}=2 \mathrm{x}=18$, diakineses with $10_{\Perp} \mathrm{G}, \mathrm{H}$, Stiburus conrathii, Du Plessis 19, $2 \mathrm{n}=2 \mathrm{x}=20$ : G, metaphase I; H, diakineses with $10_{\| l}$. Scale bar: $8 \mu \mathrm{m}$. 


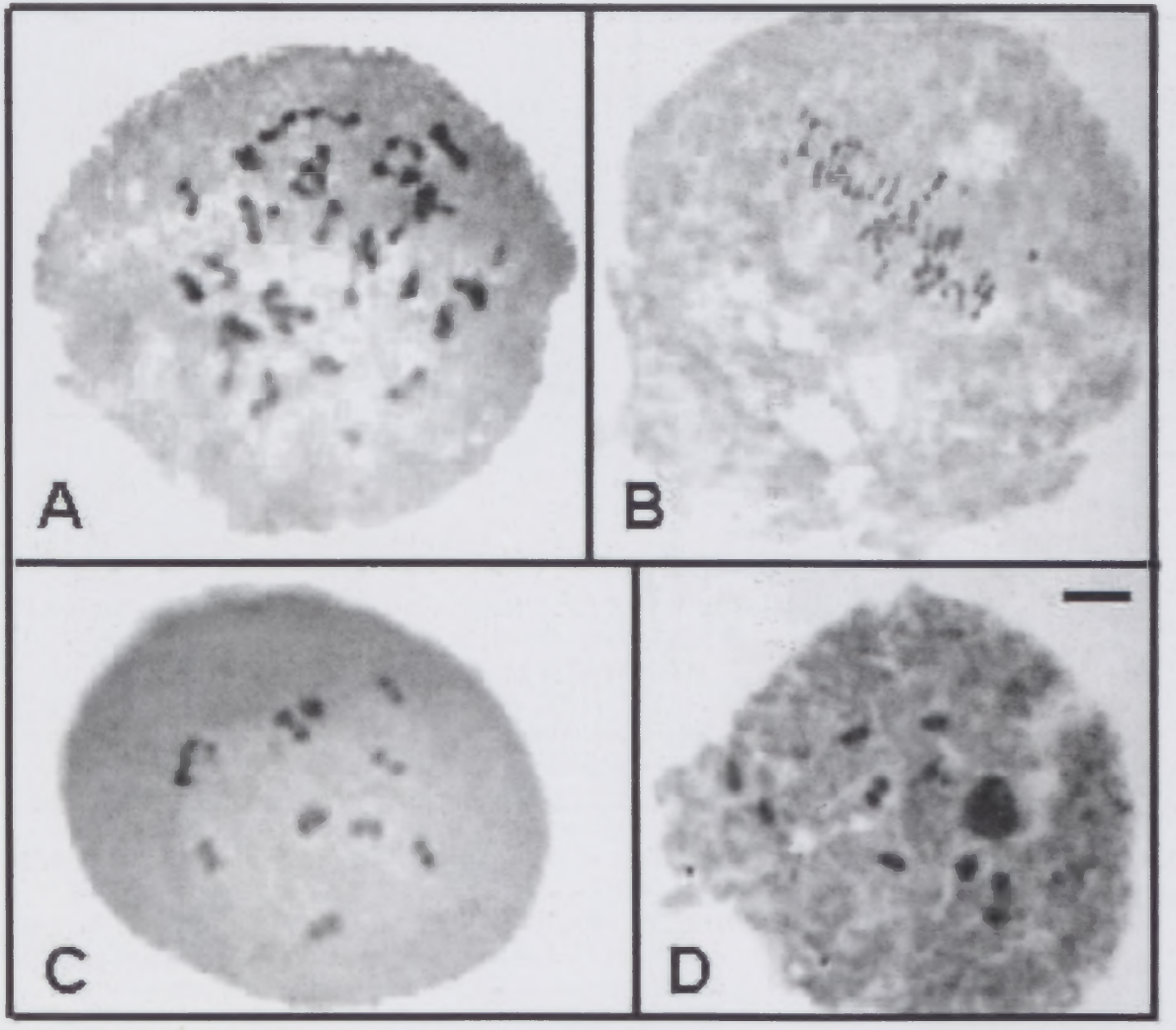

FIGURE 12.-Meiotic chromosomes in Enneapogon. A, B, E. cenchroides, Spies 2709. $2 \mathrm{n}=6 \mathrm{x}=60$ : $A$, diakinesis with $30_{n}$; B, metaphase I. C D, E. pretoriensis, Spies $3716,2 \mathrm{n}=2 \mathrm{x}=20$, diakine sis with $10 \mathrm{ll}$. Scale bar: A, C, $\mathrm{D}, 5 \mu \mathrm{m} ; \mathrm{B}, 8 \mu \mathrm{m}$.

1931; Moffet \& Hurcombe 1949) and corroborates tetraploidy present in this species. Previously only tetraploid levels were observed in the species $E$. tenuifolia (Ornduff 1967; Moore 1973, 1977; Goldblatt 1983). Here we report on a diploid specimen from Siteki in Swaziland. Univalents were observed in some cells in this specimen. The tetraploid chromosome count for $E$. trichophora reported here is the second for the species (Davidse et al. 1986) and a hexaploid specimen was reported by Spies \& Jonker (1987). One previous report of $2 \mathrm{n}=4 \mathrm{x}=40$ for $E$. racemosa (Ornduff 1967) is confirmed in this study where three tetraploid specimens were found.

Two Fingerhuthia africana specimens were investigated and were tetraploid $(\mathrm{n}=2 \mathrm{x}=20)$ (Figure 11A, B). Previous reports by Spies \& Du Plessis (1987) and De Wet $(1958,1960)$ also found tetraploidy in the genus, but diploidy has been reported (De Wet 1958, 1960) as well.

Odyssea Stapf is a xerophytic grass genus with two species, one indigenous to southern Africa (Clayton \& Renvoize 1986). It has a very distinct, much-branched, spiny habit, which is an adaptation to its specialized sandy and saline habitats (Phillips 1982). This is a first report for the genus. The specimen, $O$. paucinervis, was tetraploid $(n=2 x=18)$ and, therefore the basic chromosome number is 9 .

The genus Sporobolus $\mathrm{R} . \mathrm{Br}$. is cytogenetically complex and different basic chromosome numbers, $x=6,9$ and 10 may be present (Davidse et al. 1986). Five Sporobolus species were investigated. Three diploid $(S$. africanus, Spies 4508, S. ioclados, S. virginicus), one tetraploid (S. africanus, Spies 2369) and one hexaploid (S. albicans) specimen were found (Figure 11C-F). They all displayed multiples of nine and this confirms $x=9$ as the basic chromosome number for the genus (Darlington \& Wylie 1955; Pienaar 1955; Ornduff 1967, 1968, 1969; Federov 1969; Moore 1970, 1971, 1972, 1973, 1974, 1977; Goldblatt 1981, 1983, 1985, 1988; Goldblatt \& Johnson 1990, 1991, 1994, 1996, 1998). A chromosome number for $S$. albicans has not previously been published and this is the first report for the species (Figure 11F). Large-scale studies in this genus are still necessary to investigate the different basic chromosome numbers present and their possible phylogenetic relationships.

One specimen each of the two species Stiburus alopecuroides and $S$. conrathii was examined. Both were diploid $(\mathrm{n}=\mathrm{x}=10$ ) (Figure $11 \mathrm{G}, \mathrm{H})$ and this confirms chromosome counts based on multiples of 10 for the genus (Spies \& Du Plessis 1986).

A single Trichoneura grandiglumis specimen was found with a chromosome count of $n=x=10$. Moffet \& Hurcombe (1949) and De Wet \& Anderson (1956) also reported on diploid specimens.

\section{Tribe Pappophoreae}

The genus Enneapogon Desv. ex P.Beauv. is a very uniform genus in which most species ( 28 in total) closely resemble one another. Four specimens representing two species and one unidentified specimen were examined in this study (Figure 12A-D). One specimen, Enneapogon cenchroides was tetraploid with $n=2 x=20$, but another specimen was hexaploid (Figure 12A, B). Spies 5532 , the unidentified specimen, was also found to be tetraploid. A single E. pretoriensis specimen had $\mathrm{n}=\mathrm{x}=10$ (Figure 12C, D). Two basic chromosome numbers are reported for this genus, $x=9,10$ (Darlington \& Wylie ( $\mathrm{x}=9,10)$; Ornduff $1968(\mathrm{x}=10)$, $1969(x=10)$; Moore $1970(x=10), 1977(x=10)$; 


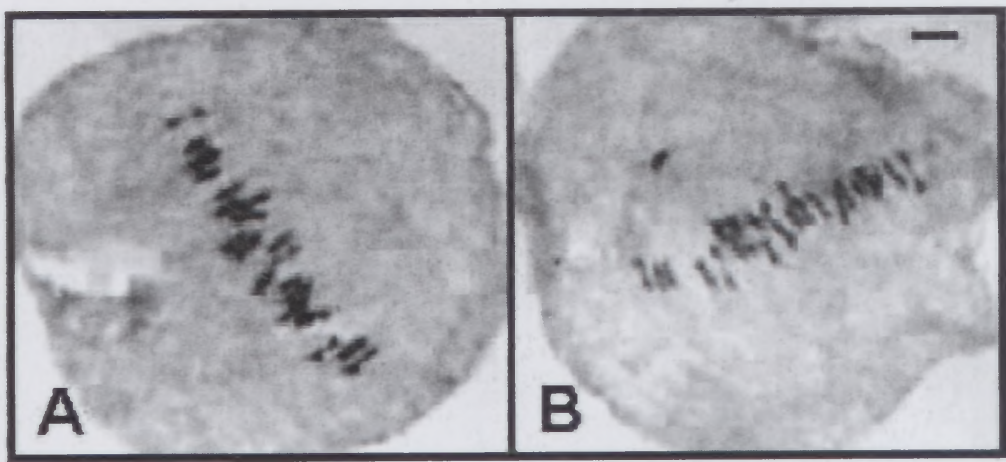

Goldblatt $1981(x=10), 1985(x=10)$; Goldblatt \& Johnson $1991(x=10), 1998(x=10)$. The majority of the studies support a basic chromosome number of ten. Only three studies, De Wet (1954), Thomas unpublished (listed Darlington \& Wylie 1955) and De Wet \& Anderson (1956) ever reported $x=9$. They found one diploid (De Wet \& Anderson 1956) and five tetraploid (De Wet 1954; Thomas (Darlington \& Wylie 1955); De Wet \& Anderson 1956) specimens based on $\mathrm{x}=9$. Davidse $e t$ al . (1986) also reported on aneuploidy in the genus.

The genus Schmidtia Steud. ex J.A.Schmidt comprises only two species, both widespread in southern Africa. Two specimens were examined representing $S$. pappophoroides and an unidentified Schmidtia species. Both were tetraploid but Spies 5536 had 0-4 B chromosomes present in some cells. This confirms the basic chromosome number of 9 for the genus (De Wet \& Anderson 1956; De Wet 1958), although Reeder \& Singh (1968) reported on a basic chromosome number of ten.

\section{Unplaced}

Centropodia Rchb. was formerly recognized as an arundinoid genus but has recently (GPWG 2001) been included in the subfamily Chloridoideae. A single specimen of this genus was investigated and found to be octaploid ( $n=4 x=24$ ) (Figure 13A, B). This confirms the basic chromosome number of the genus as six (Du Plessis \& Spies 1988; Hoshino \& Davidse 1988).

\section{CONCLUSIONS}

Chromosome numbers are reported for three of the five tribes of the subfamily Chloridoideae. Basic chromosome numbers of $\mathrm{x}=9$ and 10 occur in all the tribes. A basic chromosome number of six is also corroborated for the genus Centropodia. The high incidence of polyploidy (65\% in this study) in Poaceae and especially the southern African grasses are once again confirmed by this study.

\section{ACKNOWLEDGEMENTS}

The University of the Free State and the Foundation for Research and Development are thanked for financial assistance during this study. Henriëtte Du Plessis (formerly from the National Botanical Institute, Pretoria) and Johan Venter (UFS, Bloemfontein) are thanked for providing some meiotic material used during this study.
FIGURE 13.-Meiotic chromosomes in Centropodia glauca: A, B, Spies 5706, $2 \mathrm{n}=8 \mathrm{x}=48$, metaphase I. Scale bar: $8 \mu \mathrm{m}$.

\section{REFERENCES}

AVDULOV, N.P. 1931. Karyo-systematische untersuchung der familie Gramineen. The Bulletin for Applied Botany, Genetics and Plant Breeding 44: 1-428.

CHURCH, G.L. 1929. Meiotic phenomena in certain Gramineae. I. Festuceae, Aveneae, Agrostideae, Chlorideae, and Phalardineae. Botanical Gazette 87: 608-629.

CLAYTON, W.D. \& RENVOIZE, S.A. 1986. Genera graminum grasses of the world. Kew Bulletin. Add. Ser. XIII: 1-389.

DARLINGTON, C.D. \& WYLIE, A.P. 1955. Chromosome atlas of flowering plants: 1-519. George Allen \& Unwin, London.

DAVIDSE, G., HOSHINO, T. \& SIMON, B.K. 1986. Chromosome counts of Zimbabwean grasses and an analysis of polyploidy in the grass flora of Zimbabwe. South African Journal of Botany 52: $521-528$

DE SILVA, P.H.A.U. \& SNAYDON, R.W. 1995. Chromosome number in Cynodon dactylon in relation to ecological conditions. Annals of Botany 76: 535-537.

DE WET, J.M.J. 1954. Chromosome numbers of a few South African grasses. Cytologia 19: 97-103.

DE WET, J.M.J. 1958. Additional chromosome numbers in Transvaal grasses. Cytologia 23: 113-118.

DE WET, J.M.J. 1960. Chromosome numbers and some morphological attributes of some South African grasses. American Journal of Botany 47: $44-49$

DE WET, J.M.J. \& ANDERSON, L.J. 1956. Chromosome numbers in Transvaal grasses. Cytologia 21: 1-10.

DE WINTER, B. 1955. Eragrostis. In D. Meredith, The grasses and pastures of south Africa. Central News Agency, Cape Town.

DU PLESSIS, H. \& SPIES, J.J. 1988. Chromosome studies on African plants. 8. Bothalia 18: 119-122.

EDWARDS, D. \& LEISTNER, O.A. 1971. A degree reference system for citing biological records in southern Africa. Mitteilungen der Botanischen Staatssammlung, München 10: 501-509.

FEDEROV, A.A. 1969. Chromosome numbers in flowering plants. Academy of Sciences, Leningrad, USSR.

FISH, L. 2000. Poaceae. In O.A. Leistner, Seed plants of southern Africa: families and genera. Strelitzia 10: 659-723. National Botanical Institute, Pretoria.

GIBBS RUSSELL, G.E. \& SPIES, J.J. 1988. Variation in important pasture grasses: I. Morphological and geographical variation. Journal of the Grassland Society of Southern Africa 5: 15-21.

GIBBS RUSSELL, G.E., WATSON, L., KOEKEMOER, M., SMOOK, L., BARKER, N.P., ANDERSON, H.M. \& DALLWITZ, M.J. 1990. Grasses of southern Africa. Memoirs of the Botanical Survey of South Africa No. 58: 1-437.

GOLDBLATT, P. 1981. Index to plant chromosome numbers 1975-1978. Monographs in Systematic Botany 5: 363-418.

GOLDBLATT, P. 1983. Index to plant chromosome numbers 1979-1981. Monographs in Systematic Botany 8: 279-315.

GOLDBLATT, P. 1985. Index to plant chromosome numbers 1982-1983. Monographs in Systematic Botany 13: 147-163.

GOLDBLATT, P. 1988. Index to plant chromosome numbers 1984-1985. Monographs in Systematic Botany 23: 161-180.

GOLDBLATT, P. \& JOHNSON, D.E. 1990. Index to plant chromosome numbers 1986-1987. Monographs in Systematic Botany 30: $141-157$

GOLDBLATT, P. \& JOHNSON, D.E. 1991. Index to plant chromosome numbers 1988-1989. Monographs in Systematic Botany 40: 149-162. 
GOLDBLATT, P. \& JOHNSON, D.E. 1994. Index to plant chromosome numbers 1990-1991. Monographs in Sistematic Botany 51: $156-180$

GOLDBLATT, P. \& JOHNSON. D.E. 1996. Index to plant chromosome numbers 1992-1993. Monographs in Sistematic Botany 58: $167-186$.

GOLDBLATT. P. \& JOHNSON. D.E. 1998. Index to plant chromosome numbers 1994-1995. Monographs in Systematic Botany 69: $121-142$

GOLDBLATT. P. \& JOHNSON. D.E. 2000). Index to plant chromosome numbers 1996-1997. Monographs in Systematic Botany 81: 110-118.

GOULD. F.W. \& SODERSTROM. T.R. 1974. Chromosome numbers of some Ceylon grasses. Canadian Journal of Botany 52 : 1075-1090.

GRASS PHYLOGENY WORKING GROUP. 20(0)1. Phylogeny and subfamilial classification of the grasses (Poaceae). Annals of the Missouri Botanical Garden 88: 373-457.

HARTLEY, W. 1964. The distribution of the grasses. In C. Barnard. Grasses and grasslands: 26-49. Macmillian. London.

HILU. K.W. \& ALICE. L.A. 2001. A phylogeny of Chloridoideae (Poaceae) based on matK sequences. Systematic Botany 26 : $386-405$

HOSHINO. T. \& DAVIDSE. G. 1988. Chromosome numbers of grasses (Poaceae) from southern Africa. I. Annals of the Missouri Botanical Garden 75: 866-873

HUNTER. A.W.S. 1934. A karyosystematic investigation in the Gramineae. Canadian Journal of Research 11: 213-241

MCNEILL. J. 1979. Diplachne and Leptochloa (Poaceae) in Nonh America. Brittonia 31: 399-404.

MCVAUGH. R. 1983. A descriptive account of the vascular plants of New Mexico. Flora Nowo Galiciana 14: 1-436. Ann Arbor. University of Michigan Press.

MOFFET. A.A. \& HURCOMBE. R.E. 1949. Chromosome numbers in South African grasses. Heredity 3: 369-373.

MOORE. R.J. 1970. Index to plant chromosome numbers for 1968 . Regnum Vegetabile 68: 18-28.

MOORE. R.J. 1971. Index to plant chromosome numbers for 1969 Regnum Vegetabile 77: 7-13.

MOORE. R.J. 1972. Index to plant chromosome numbers for 1970 Regnum Vegetabile 84: 13-24

MOORE. R.J. 1973. Index to plant chromosome numbers for 1967-1971. Regnum Vegetabile 90: 50-88.

MOORE. R.J. 1974. Index to plant chromosome numbers for 1972. Regnum Vegetabile 91: 8-16.

MOORE. R.J. 1977. Index to plant chromosome numbers for 1973/74. Regmum Vegetabile 96: 104-123.

ORNDUFF, R. 1967. Index to plant chromosome numbers for 1965 Regnum Vegetahile 50: 26-37.

ORNDUFF. R. 1968. Index to plant chromosome numbers for 1966 Regnum Vegetabile 55: 14-26.

ORNDUFF. R. 1969. Index to plant chromosome numbers for 1967 Regnum Vegetabile 59: 20-29.

PETERSON. P.M., WEBSTER. R.D. \& VALDES-REYNA. J. 1997 Genera of the new world Eragrostideae (Poaceae: Chloridoi deae). Smithsonian Contributions to Botany 87: 1-50.

PHILLIPS. S.M. 1972. A survey of the genus Eleusine Gaertn. (Gramineae) in Africa. Kew Bulletin 27: 251-270.

PHILLIPS. S.M. 1982. A numerical analysis of the Eragrostideae (Gramineae). Kew Bulletin 37: 133-162.

PIENAAR. R.DE V. 1953. Cytological studies in some south African species of the genus Eragrostis Host. Unpublished Ph.D. thesis, University of the Witwatersrand. Johannesburg.

PIENAAR. R.DE V. 1955. The chromosome numbers of some indigenous South African and introduced Gramineae. In C. Meredith. The grasses and pastures of South Africa: 551-570. Central News Agency, Cape Town.

REEDER. J.R. \& SINGH. D.N. 1968. Chromosome numbers in the tribe Pappophoreae (Gramineae). Madrono 19: 183-187.

SMOOK. L. 1990. Eragrostis N.M.Wolf. In G.E Gibbs Russell et al Grasses of southem Africa. Memoirs of the Botanical Survey of South Africa No. 58: 139-163. Botanical Research Institute. Pretoria.

SPIES. J.J. 1984. A cytotaxonomic study of Lantana camara (Verbenaceae) from South Africa. South African Journal of Botany 3: 231-250.

SPIES. J J. \& DU PLESSIS. H. 1986. Chromosome studies on African plants. 1. Bothalia 16:87.88.

SPIES. J.J. \& DU PLESSIS. H. 1987. Chromosome studies on African plants. 5. Bothalia 17: 257-259.

SPIES, J.J. \& JONKER, A. 1987. Chromosome studies on African plants. 4. Bothalia 17: 135, 136.

SPIES. J.J. \& VOGES. S.P. 1988. Chromosome studies on African plants. 7. Bothalia 18: 114-119.

SPIES. J.J., VAN DER MERWE. E.. DU PLESSIS. H. \& SAAYMAN. E.J.L. 1991. Basic chromosome numbers and polyploid levels in some South African and Australian grasses (Poaceae). Bothalia 21: 163-170.

SPIES J J SPIES S.K VAN WYK. S.M. MALAN A.F \& LIEBEN BERG. E.J.L. 1996. Cytogenetic studies of the subfamily Pooideae (Poaceae) in South Africa. 1. The tribe Aveneae, subtribe Aveninae. Bothalia 26: 53-61.

STRYDOM. A. \& SPIES. J.J. 1994. A cytotaxonomic study of some representatives of the tribe Cynodonteae (Chloridoideae. Poaceae). Bothalia 24: 92-96.

VAN DEN BORRE. A. \& WATSON. L. 1994. The infrageneric classification of Eragrostis (Poaceae). Taxon 43: 383-422.

VORSTER. T.B. \& LIEBENBERG. H. 1977. Cytogenetic studies in the Eragrostis cunula complex. Bothalia 12: 215-221.

WATSON. L. \& DALLWITZ. M.J. (1992 onwards). Grass genera of the world: 1-1044. CAB International. Wallingford. Oxon. Version 18th August 1999.

R, ROODT*and J J. SPIES*

* Department of Plant Sciences: Genetics (62). University of the Free State. P.O. Box 339, 9300) Bloemfontein

MS received: 2002-02-27. 